\title{
Article
}

\section{Bioactivity of Essential Oils for Mitigation of Listeria monocytogenes Isolated from Fresh Retail Chicken Meat}

\author{
Alaa Eldin M. A. Morshdy ${ }^{1}$, Mohammed S. Al-Mogbel ${ }^{2}$, Mohamed E. M. Mohamed ${ }^{3}$ D, \\ Mohamed Tharwat Elabbasy ${ }^{1,4}$ (D), Azza K. Elshafee ${ }^{1, *}$ and Mohamed A. Hussein ${ }^{1}$ \\ 1 Food Control Department, Faculty of Veterinary Medicine, Zagazig University, Zagazig 44519, Egypt; \\ A.Morshedy@zu.edu.eg (A.E.M.A.M.); mt.elabbasy@uoh.edu.sa (M.T.E.); elged2010@yahoo.com (M.A.H.) \\ 2 Clinical Laboratory Sciences Department, College of Applied Medical Sciences, Ha'il University, \\ Ha'il P.O. Box 2240, Saudi Arabia; msm_hhscb@hotmail.com \\ 3 Zoonoses Department, Faculty of Veterinary Medicine, Zagazig University, Zagazig 44519, Egypt; \\ bishet68@yahoo.de \\ 4 Public Health Department, College of Public Health and Health Informatics, Ha'il University, \\ Ha'il P.O. Box 2240, Saudi Arabia \\ * Correspondence: aza.khaled@vet.zu.edu.eg; Tel.: +20-1147560577
}

\section{check for} updates

Citation: Morshdy, A.E.M.A.; Al-Mogbel, M.S.; Mohamed, M.E.M.; Elabbasy, M.T.; Elshafee, A.K.; Hussein, M.A. Bioactivity of Essential Oils for Mitigation of Listeria monocytogenes Isolated from Fresh Retail Chicken Meat. Foods 2021, 10, 3006. https://doi.org/10.3390/ foods10123006

Academic Editor: Amin

Mousavi Khaneghah

Received: 9 October 2021

Accepted: 23 November 2021

Published: 4 December 2021

Publisher's Note: MDPI stays neutra with regard to jurisdictional claims in published maps and institutional affiliations.

Copyright: (c) 2021 by the authors. Licensee MDPI, Basel, Switzerland. This article is an open access article distributed under the terms and conditions of the Creative Commons Attribution (CC BY) license (https:// creativecommons.org/licenses/by/ $4.0 /)$.

\begin{abstract}
Listeria monocytogenes is one of the most severe foodborne pathogens found in several habitats. Therefore, this study aims to investigate the antilisterial activity of different essential oils (EOs) against multidrug-resistant (MDR) L. monocytogenes strains isolated from fresh chicken meat. Our results showed that the prevalence of L. monocytogenes in the examined samples was $48 \%$. Seventy-eight isolates were identified as L. monocytogenes. Out of these, $64.1 \%$ were categorized as MDR and were categorized in 18 patterns with $50 \mathrm{MDR}$ isolates. One isolate was selected randomly from each pattern to investigate their biofilm-forming ability, resistance, and virulence genes incidence. Out of 18 MDR isolates, $88.9 \%$ showed biofilm-forming ability. Moreover, the most prevalent resistance genes were $\operatorname{ermB}(72 \%)$, aad $\mathrm{A}(67 \%)$, pen $\mathrm{A}(61 \%)$, and floR genes $(61 \%)$. However, the most prevalent virulence genes were inlA $(94.4 \%)$, prf A (88.9\%), plcB (83.3\%), and $\operatorname{acta\mathrm {A}}(83.3 \%)$. The antilisterial activity of EOs showed that cinnamon bark oil (CBO) was the most effective antilisterial agent. $\mathrm{CBO}$ activity could be attributed to the bioactivity of cinnamaldehyde which effects cell viability by increasing the bacterial cell electrical conductivity, ion leakage, and salt tolerance capacity loss. Therefore, $\mathrm{CBO}$ could be an effective alternative natural agent for food safety applications.
\end{abstract}

Keywords: Listeria monocytogenes; antimicrobial agents; essential oils; multidrug-resistance; foodborne disease

\section{Introduction}

Despite modern advances in food processing and preservation techniques, food protection is a growing public health concern [1]. In particular, the survival of microorganisms in foods is a critical concern, as it can cause food spoilage, infection, and illness [2]. Listeria monocytogenes is considered one of the primary foodborne pathogens because of its widespread prevalence and high tolerance against severe environmental conditions such as salt, temperature, and $\mathrm{pH}$, among all known Listeria spp. [3]. L. monocytogenes is a foodborne pathogen that can be found in various food products and is considered a significant concern for foodborne bacterial pathogens [4]. Clinical disease caused by $L$. monocytogenes infections varies from gastroenteritis with fever to invasive infections that require hospitalization and may result in death [1].

L. monocytogenes, the main cause of listeriosis, is an intracellular bacterium that can invade several cell types. In addition, L. monocytogenes can cross the intestinal and cross barriers between the blood vessels of the brain and placenta in the case of pregnancy and 
even could affect the fetus [5]. Human listeriosis is a foodborne disease associated with the ingestion of infected food products, with a mortality rate reaching up to 20\% [6].

Different preservation methods (chemical preservatives, refrigeration, and heating) have been commonly used throughout food production to control foodborne pathogens. On the other hand, incomplete inactivation of pathogenic agents was widely documented, and post-treatment contamination may reintroduce pathogenic agents into food products [7-9]. Furthermore, consumers' fear is increasing concerning the use of chemical preservatives in the food industry due to their possible side effects and toxicity [10]. Therefore, tremendous effort has been expended in creating alternative natural additives for improving the quality of food products, in particular the microbiological quality.

Plant essential oils (EOs) and extracts consider a natural antimicrobial source in the foods industry as preservation and flavoring agents [7-12]. Plant extracts are generally healthy according to the modern extensive toxicological studies and due to a lack of known adverse impact during historical use [10]. Plant extracts contain a high concentration of phytochemical compounds and secondary metabolites that inhibit pathogenic agents [13]. Plant extracts have been proven to have wide antimicrobial efficacy toward foodborne pathogenic bacteria such as E. coli, Listeria innocua [14], and L. monocytogenes [15,16]. Natural food additives are commonly used, such as Proallium (garlic and onion extracts) [17] and Cycrom (20\% citrus extract and organic acids) [18], which have already been commercialized. However, it is estimated that only $10 \%$ of the world's $250,000-500,000$ plant species have been assessed, and few studies have investigated the chemical composition and the mode of action of plant extracts [19]. Therefore, it is important to investigate the activity of different plant extracts and essential oils as antimicrobial agents against food products spoilage pathogens such as L. monocytogenes to indicate their potential in food safety applications.

Despite the importance of chicken meat in the Egyptian market, few studies have been conducted to study L. monocytogenes in fresh marketed chicken meat in Zagazig City, Egypt. As well, to the best of our knowledge, this study is the first to explore antibiotic-resistant bacterial strains in these markets and at the same time investigate the effect of traditional oils on these bacterial strains. Therefore, this study aims to achieve the following goals:

1. Investigate the prevalence of L. monocytogenes in fresh retail chicken meat;

2. $\quad$ Detect the antibiogram profile of the isolated L. monocytogenes;

3. Evaluate the biofilm-forming ability (BFA), virulence, and resistance genes;

4. Investigate the activity of different EOs as antimicrobial agents against multidrugresistant L. monocytogenes;

5. Study the effect of EOs on bacterial cell viability and integrity loss, as indicated by increased electrical conductivity, ion leakage, and salt tolerance capacity loss.

The results obtained in this study are expected to reveal valuable details about the bioactivity of EOs as antilisterial agents and expand our understanding of the antibacterial mechanism. Thus, this study could contribute to food preservative and pharmaceutical industries applications.

\section{Materials and Methods}

\subsection{Sampling}

As illustrated in the experimental setup, Figure 1, seventy-five fresh retail chicken meat samples, including breasts, thighs, and livers, were used in this study and randomly collected from 12 different supermarkets and four different brands in ElSharkia, Egypt, from April to November 2020. Afterward, to avoid cross-contamination, each sample was labeled and delivered in a sterile plastic storing bag and transferred in a cooling icebox $\left(4^{\circ} \mathrm{C}\right)$ immediately to the hygienic food laboratory, Faculty of Veterinary Medicine, ElSharkia University, within three hours after sampling and immediately analyzed. 

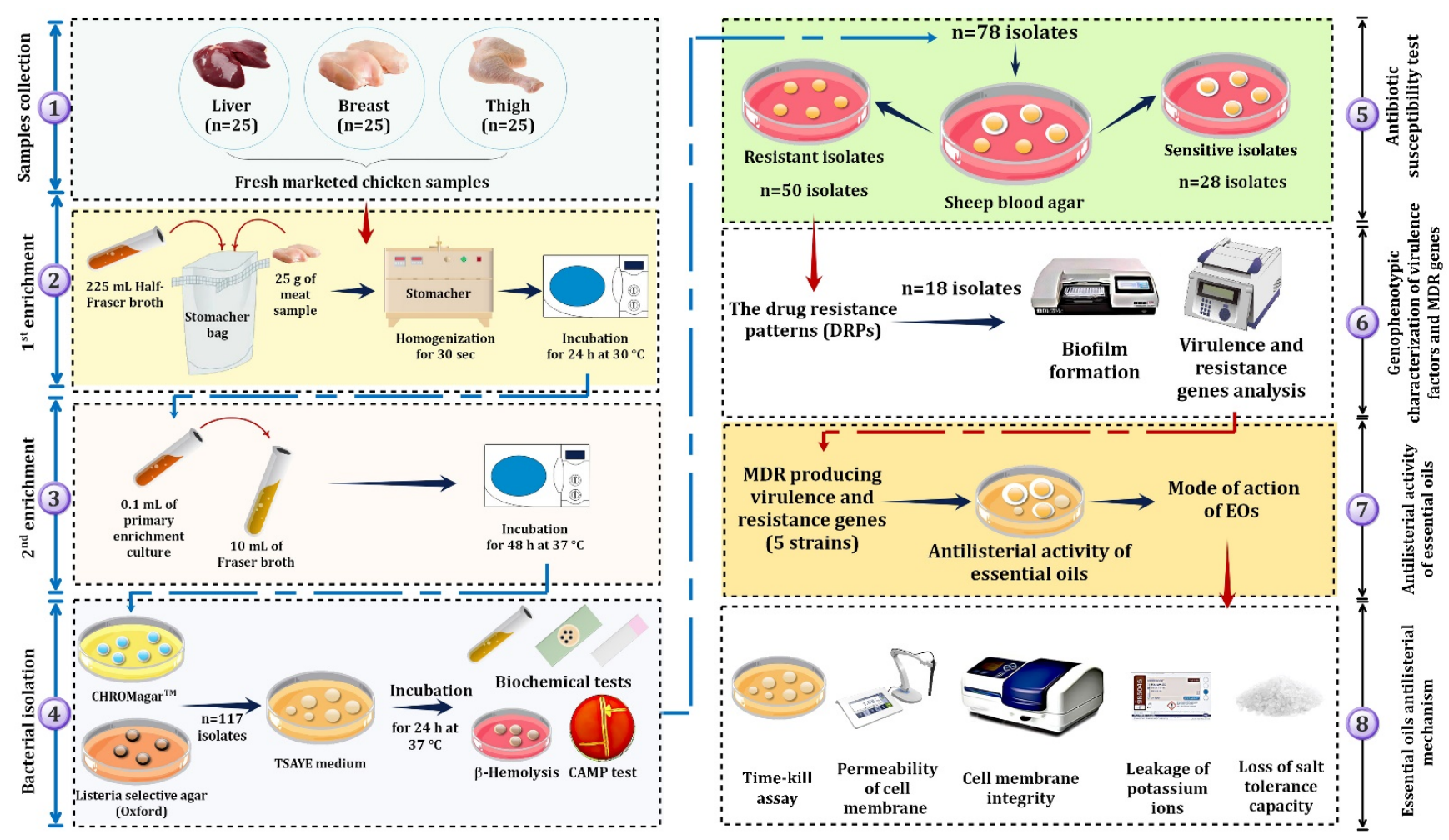

Figure 1. Schematic diagram of the experimental setup design for screening and characterizing L. monocytogenes isolated from fresh retail chicken meat samples.

\subsection{Isolation of L. monocytogenes}

All collected samples were examined for L. monocytogenes incidence based on the International Standards Organization guidelines [20]. As shown in Figure 1, the primary enrichment and secondary enrichment were performed for chicken meat samples. Afterward, for the bacterial isolation, a loopful of enrichment cultures was streaked on Listeria Selective Agar (Oxoid Hampshire, UK) supplemented with SR0140E (Oxford formulation) and CHROMagarTM Listeria (CHROMagar, Paris, France).

On CHROMagar ${ }^{\mathrm{TM}}$, blue colonies surrounded by a white halo were isolated, while on Oxford agar, brown colonies surrounded by a black halo were isolated. To purify the colonies, they were streaked on the surface of trypticase soy agar supplemented with $0.6 \%$ yeast extract (TSAYE) and incubated for $24 \mathrm{~h}$ at $37^{\circ} \mathrm{C}$. Gram staining, oxidase, catalase, motility, spore formation, acid production from mannitol, D-Xylose, and L-Rhamnose tests were used to confirm the colonies from TSAYE as L. monocytogenes. Additionally, $\beta$ hemolytic activity and Christine-Atkins-Munch-Petersen (CAMP) were performed based on Bergey's Manual of Systematic Bacteriology [21]. A stock culture of L. monocytogenes serotype 1/2b and Staphylococcus aureus ATCC 25923 were obtained from the Food Control Department, Zagazig University [22] and used as reference strains for biochemical tests and the CAMP test, respectively.

\subsection{Antibiotics Susceptibility Test}

In order to detect MDR L. monocytogenes isolates, fresh bacterial colonies of L. monocytogenes isolates were separately grown at $37^{\circ} \mathrm{C}$ in brain heart infusion broth (BHI; Merck, Darmstadt, Germany) for $24 \mathrm{~h}$, and each inoculum was cultured on Mueller Hinton Agar (MHA) with 5\% sheep blood (Merck, Darmstadt, Germany). Susceptibility to 14 different antibiotics (MAST, Merseyside, UK) is listed in Table 1. The antibiotic selection was performed based on its effectiveness against Gram-positive bacteria. The antibiotics susceptibility test (AST) was determined using the standard disk diffusion Kirby-Bauer [23]. The inhibition zone diameters (IZD) were measured, including the disc diameter, the re- 
sults were interpreted as resistant, intermediate, or susceptible, according to Clinical and Laboratory Standards Institute [24] for S. aureus ATCC 25923 because of the lack of specific standards for L. monocytogenes [25] (Table S1). The multiple antibiotic resistance (MAR) index was calculated according to Osundiya et al. [26].

Table 1. The resistance of $L$. monocytogenes strains against different antimicrobial agents $(n=78)$.

\begin{tabular}{|c|c|c|c|c|c|c|c|}
\hline \multirow{2}{*}{ Antibiotics } & \multirow{2}{*}{$\begin{array}{l}\text { Concentration } \\
(\mu \mathrm{g} / \mathrm{Disc})\end{array}$} & \multicolumn{2}{|c|}{ Resistant } & \multicolumn{2}{|c|}{ Intermediate } & \multicolumn{2}{|c|}{ Susceptible } \\
\hline & & No. & $(\%)$ & No. & $(\%)$ & No. & $(\%)$ \\
\hline Ampicillin (AMP) & 10 & 22 & 28.2 & 4 & 5.13 & 52 & 66.67 \\
\hline Chloramphenicol (CHL) & 30 & 29 & 37.2 & 2 & 2.56 & 47 & 60.26 \\
\hline Ciprofloxacin (CIP) & 5 & 29 & 37.2 & 5 & 6.41 & 44 & 56.41 \\
\hline Clindamycin (CLI) & 2 & 36 & 46.2 & 1 & 1.28 & 41 & 52.56 \\
\hline Erythromycin (ERY) & 15 & 48 & 61.5 & 5 & 6.41 & 25 & 32.05 \\
\hline Gentamicin (GEN) & 120 & 57 & 73.1 & 7 & 8.97 & 14 & 17.95 \\
\hline Imipenem (IPM) & 10 & 29 & 37.2 & 2 & 2.56 & 47 & 60.26 \\
\hline Linezolid (LNZ) & 30 & 29 & 37.2 & 5 & 6.41 & 44 & 56.41 \\
\hline Nalidixic acid (NAL) & 30 & 29 & 37.2 & 5 & 6.41 & 44 & 56.41 \\
\hline Oxacillin (OXA) & 1 & 29 & 37.2 & 4 & 5.13 & 45 & 57.69 \\
\hline Rifampicin (RIF) & 5 & 22 & 28.2 & 6 & 7.69 & 50 & 64.10 \\
\hline Tetracycline (TET) & 30 & 48 & 61.5 & 6 & 7.69 & 24 & 30.77 \\
\hline Trimethoprim (TMP) & 5 & 36 & 46.2 & 5 & 6.41 & 37 & 47.44 \\
\hline Vancomycin (VAN) & 30 & 22 & 28.2 & 4 & 5.13 & 52 & 66.67 \\
\hline
\end{tabular}

\subsection{Molecular Identification, Resistance, and Virulence Genes Detection}

The selected isolates based on AST results were grown on Tryptone Soy Yeast Extract Agar (TSYEA) to extract the bacterial DNA and perform PCR assay as described by Osman et al. [27]. The genus was confirmed by PCR assay using specific primers for L. monocytogenes $16 \mathrm{~S}$ rRNA gene (Supplementary Materials, Table S2) [28-36]. Amplification conditions were denatured $\left(94^{\circ} \mathrm{C}\right.$ for $\left.4 \mathrm{~min}\right)$, then followed by 25 amplification cycles $\left(60 \mathrm{~s}\right.$ at $94{ }^{\circ} \mathrm{C}, 60^{\circ} \mathrm{C}$ for $60 \mathrm{~s}$, and $72{ }^{\circ} \mathrm{C}$ for $60 \mathrm{~s}$ ) with a final extension $\left(5 \mathrm{~min}\right.$ at $72{ }^{\circ} \mathrm{C}$ ). Escherichia coli strain (ATCC 25922) and L. monocytogenes strain (ATCC 19115) were used as negative and positive control, respectively. The presence of Listeria pathogenicity island (LIPI-1) virulence genes (plcA, plcB, $\operatorname{prf} \mathrm{A}$, and $\operatorname{act} \mathrm{A})$, an adhesion protein (lap), internalin proteins encoding genes (inl $\mathrm{A}$, inl $\mathrm{B}$, inlC, and inlJ), Listeriolysin $\mathrm{O}$ gene (hlyA), and a flagellin protein ( $f l a \mathrm{~A})$ were detected. In addition, the presence of resistance-encoding genes, namely, aminoglycoside adenyltransferase ( $\operatorname{aadA}$ ), $\beta$-lactamase-ampicillin resistance gene $(\operatorname{amp} \mathrm{C})$, vanillate o-demethylase oxygenase subunit (van $\mathrm{A}$ and $\operatorname{van} \mathrm{B})$; erythromycin resistance genes (ere $\mathrm{A}$, ere $\mathrm{B}$, and $\operatorname{erm} \mathrm{B})$; penicillin-binding protein gene (pen $\mathrm{A})$, florfenicol export protein (flo R), chloramphenicol transporter nonenzymatic chloramphenicol-resistance protein $(\mathrm{cmlA})$, the tetracycline resistance genes $($ tet $\mathrm{A}$ and tet $\mathrm{B})$ were detected using primers that are listed in the Supplementary Materials, Table S3 [37-43], and the PCR assay was performed as described by Osman et al. [27]. The PCR assay was performed on the selected isolates and reference strains. The resulting DNA sequence data were compared to data in the GenBank database using the BLAST algorithm available at the National Center for Biotechnology Information website. The phylogenetic analysis was performed using Mega 6 software. The phylogenetic tree analysis was constructed using the maximum-likelihood method.

\subsection{Biofilm Quantification}

The microtiter plate assay (MPA) was carried out according to Lee et al. [44] with minor modifications. In brief, selected overnight growing colonies were diluted to obtain an $\mathrm{OD}_{600}$ of 0.1 in each growth medium. A volume of $200 \mu \mathrm{L}$ of the bacterial solution was transferred to 96-well microplates in triplicate wells. As a negative control, a sterile medium was used. Microplates were incubated for $24 \mathrm{~h}$ in static conditions at $30^{\circ} \mathrm{C}$. Plates were placed upside down, and then planktonic cells and the media were removed by 
tapping gently. Wells were washed using sterile saline solution $(300 \mu \mathrm{L} ; 8.5 \mathrm{~g} \mathrm{NaCl} / \mathrm{L})$ to remove loosely attached bacteria. Afterward, biofilms were fixed with $300 \mu \mathrm{L}$ of ethanol $(96 \% v / v)$ for $20 \mathrm{~min}$ then dried at $25{ }^{\circ} \mathrm{C}$ after ethanol removal.

For bacterial staining, $220 \mu \mathrm{L} /$ well of crystal violet $(0.1 \% w / v$; CV; Merck, Darmstadt, Germany) was added, and plates were incubated in static conditions for $30 \mathrm{~min}$. The solution was then removed by sharply placing the plates upside down. Wells were washed three times with $300 \mu \mathrm{L}$ of saline solution and dried at $25^{\circ} \mathrm{C}$, then filled with acetic acid $(150 \mu \mathrm{L} ; 33 \% v / v)$. Plates were set on a plate shaker for $10 \mathrm{~min}$ with slight agitation, and the amount of destained $\mathrm{CV}$ was assessed by reading $\mathrm{OD}_{600}$ using a microplate reader (BioTek EL800; Winooski, VT, USA). The experiment was performed in triplicates.

\subsection{Gas Chromatography/Mass Spectrometry (GC/MS) Analysis of EOs}

Seven EOs, namely, cinnamon bark oil (CBO), thyme (wild) oil (TWO), thyme (red) oil (TRO), thyme (geraniol) oil (TGO), coriander oil (CRO), lavender (true) oil (LTO), and rosemary oil (RO), were purchased from National Research Center (NRC Cairo, Egypt) based on their antilisterial activity in a literature survey and their use in traditional medicine [7-12,15] to evaluate their antilisterial activity against MDR L. monocytogenes. EOs were stored at $4{ }^{\circ} \mathrm{C}$ for further experiments. EOs chemical composition analysis was assessed using the Agilent 6890 $\mathrm{N}$ gas chromatograph (Agilent Technologies; Palo Alto, CA, USA) equipped with an HP-5MS capillary column $(30 \mathrm{~m} \times 0.25 \mathrm{~mm} \times 0.25 \mu \mathrm{m})$. The oven temperature was adjusted to increase from 60 to $250{ }^{\circ} \mathrm{C}$ at a rate of $4{ }^{\circ} \mathrm{C}$ per min for $15 \mathrm{~min}$. Transfer line temperature was $250{ }^{\circ} \mathrm{C}$. Helium was used as the carrier gas with a flow rate of $1 \mathrm{~mL} / \mathrm{min}$. The EO sample was diluted in pentane, and the injection volume was $1 \mu \mathrm{L}$, while the split/splitless injector temperature was set at $280^{\circ} \mathrm{C}$. The EO sample was injected in the split mode with a split ratio of $40.8 / 1$. However, a quadrupole mass spectrometer was scanned over the $35-465 \mathrm{~m} / \mathrm{z}$ with an ionizing voltage of $70 \mathrm{eV}$ and an ionization current of $150 \mathrm{~mA}$. MS ion source and MS quadrupole temperatures were $230{ }^{\circ} \mathrm{C}$ and $150{ }^{\circ} \mathrm{C}$, respectively. EOs compositions were identified by comparison of their mass spectra (MS) and retention indices (RI) the Wiley Registry of Mass Spectral Data, 6th Edition (Wiley Interscience, New York, NY, USA).

\subsection{Antilisterial Activity of EOs}

EOs were diluted using Tween $20(0.5 \%, v / v)$ [45] at the following concentrations 0.5, $0.25,0.15$, and $0.1 \%(v / v)$ and filtered using sterilized nylon syringe filters $(0.22 \mu \mathrm{m})$. The antimicrobial activity was assessed by a standard disc diffusion assay [46]. Briefly, MHA plates were inoculated using $200 \mu \mathrm{L}$ of bacterial suspension $\left(10^{6} \mathrm{CFU} / \mathrm{mL}\right)$ on the agar surface. Afterward, the paper disk ( $6 \mathrm{~mm}$; Biomérieux, Lyon, France) was impregnated with $20 \mu \mathrm{L}$ of each concentration and placed on MHA plates surface (Oxoid, Badhoevedorp, Netherlands). As a control, Tween 20 was used. The prepared plates were then incubated for $24 \mathrm{~h}$ at $37^{\circ} \mathrm{C}$. Ampicillin $(10 \mu \mathrm{g} /$ disk $)$ was used as reference controls. The antibacterial activity was assessed by measuring the mean of inhibitory zones diameters. The experiment was performed in triplicates.

An EO that exhibited efficient antibacterial activity was selected to detect the minimum inhibitory concentration (MIC) and the minimum bactericidal concentration (MBC) by the broth dilution technique. Briefly, one colony of each bacterial strain was sampled and inoculated in $25 \mathrm{~mL}$ brain heart infusion broth and incubated at $37{ }^{\circ} \mathrm{C}$ for $24 \mathrm{~h}$ to obtain a bacterial suspension of $10^{9} \mathrm{CFU} / \mathrm{mL}$, then diluted with buffered peptone water to achieve $10^{5} \mathrm{CFU} / \mathrm{mL}$ bacterial suspensions. Serial dilutions of EOs with a concentration ranging from $0.125-2.5 \% v / v$ were prepared with brain heart infusion broth and mixed with bacterial suspensions to give a volume of $4 \mathrm{~mL}$ and a final concentration of bacteria of approximately $5 \times 10^{4} \mathrm{CFU} / \mathrm{mL}$ and incubated at $37^{\circ} \mathrm{C}$ for $24 \mathrm{~h}$. The MIC was considered as the lowest concentration that inhibits visible growth. The $\mathrm{MBC}_{90}$ was determined by subculturing $100 \mu \mathrm{L}$ from each negative test tube onto plate count agar plates. $\mathrm{MBC}_{90}$ was defined as the lowest concentration of the antimicrobial agent that inhibits $\geq 90 \%$ of bacterial isolates. 


\subsection{Detection of Essential Oil Bioactivity}

\subsubsection{Time-Kill Assay}

The effect of EOs on L. monocytogenes viability was investigated using a time-kill assay, according to Li et al. [47]. Briefly, a bacterial culture treated with EOs at the MIC was taken as the treatment sample, and dimethyl sulfoxide ( $5 \%$, DMSO) was used as a control. The prepared cultures were incubated for $8 \mathrm{~h}$ at $37^{\circ} \mathrm{C}$. The samples were collected every $2 \mathrm{~h}$ and diluted in phosphate-buffer ( $\mathrm{pH}$ 7.4), then inoculated over the nutrient agar and incubated for $24 \mathrm{~h}$ at $37^{\circ} \mathrm{C}$. Bacterial colonies in the treatment and control plates were counted and presented in $\log 10(\mathrm{CFU} / \mathrm{mL})$.

\subsubsection{Cytoplasmic Membrane Permeability}

L. monocytogenes cytoplasmic membrane permeability of the selected strains after the treatment using EOs was assessed according to Ye et al. [48] by evaluating the released ions into the bacterial solution supernatant, which increased the relative conductivity. This increase was assessed using a conductivity meter (Shanghai Precision Instruments Co., Ltd., Shanghai, China). The permeability of the cytoplasmic membrane was assessed based on the following equation:

$$
\text { Relative conductivity }(\%)=\left(\frac{\mathrm{RC}_{2}-\mathrm{RC}_{1}}{\mathrm{RC}_{0}}\right) \times 100
$$

where $\mathrm{RC}_{0}$ was the electrical conductivity of dead bacterial cells in glucose (5\%) after treatment for $5 \mathrm{~min}$ in boiling water; $\mathrm{RC}_{1}$ expresses the electrical conductivity of $\mathrm{EO}$ at the MIC mixed with glucose (5\%); and $\mathrm{RC}_{2}$ expresses the electrical conductivity of the treated bacterial culture with $\mathrm{EO}$ in the course of $12 \mathrm{~h}$ of incubation.

\subsubsection{Potassium Ion Leakage Assay}

The amount of leaked free potassium ions $\left(\mathrm{K}^{+}\right)$from the tested L. monocytogenes strains was evaluated as reported by Bajpai et al. [49]. After the treatment of L. monocytogenes cells with EOs at MIC mixed with $0.1 \%$ peptone water and incubated at $37^{\circ} \mathrm{C}$ for $8 \mathrm{~h}$, the concentration of extracellular free ions ( $\mathrm{K}^{+}$concentration) was tested every $2 \mathrm{~h}$ with a Kalium Potassium kit (Quantofix, Macherey-Nagel GmbH \& Co. KG, Duren, Germany). L. monocytogenes ATCC 19115 was obtained from Food Control Department, Zagazig University, then treated with 5\% DMSO and used as a control.

\subsubsection{Cell Membrane Integrity Assay}

The cell membrane integrity of the selected L. monocytogenes strains due to the action of EOs was evaluated as described by Carson et al. [50]. Bacterial samples were treated with the MIC of the most effective EO for each strain, while the control sample was treated with $5 \%$ DMSO. All samples were incubated at $37^{\circ} \mathrm{C}$. Samples were obtained every $30 \mathrm{~min}$ then centrifuged at $1000 \times g$ for $10 \mathrm{~min}$. The supernatant absorbance $\left(\mathrm{OD}_{260}\right.$ $\mathrm{nm}$ ) was measured using a spectrophotometer (SP-3000 plus, Optima, Tokyo, Japan). The absorbance corrections for the treated and control samples were performed by detecting the EOs values without bacteria in sterile peptone water.

\subsubsection{Loss of Salt Tolerance Capacity Assay}

As a result of EOs treatment, L. monocytogenes salt tolerance capacity loss was evaluated as described by Miksusanti et al. [51]. In brief, the treated bacterial culture using EOs at MIC was grown on nutrient agar plates containing various concentrations of $\mathrm{NaCl}(0,2.5$, 5.0 , and $10.0 \%$ ). Plates treated with 5\% DMSO were used as a control. The prepared plates were incubated for $24 \mathrm{~h}$ at $37^{\circ} \mathrm{C}$. Bacterial colonies were counted in samples and control plates and presented in $\log 10(\mathrm{CFU} / \mathrm{mL})$. 


\subsection{Statistical Analysis}

The data obtained were expressed as the means \pm standard deviation. One-way analysis of variance was used to detect the significant differences at $p<0.05$ using GraphPad Prism version 8 . Heatmap representations with cluster analysis were performed using NCSS 2021 Statistical Software (NCSS, LLC. Kaysville, UT, USA, ncss.com/software/ncss).

\section{Results and Discussion}

\subsection{Prevalence and Phenotypic Characterization of L. monocytogenes}

As shown in Figure 1, out of 117 bacterial isolates from 75 meat samples, 78 isolates were identified and confirmed as L. monocytogenes. Out of 75 tested samples, L. monocytogenes were detected in 36/75 (48\%) samples. The prevalence of L. monocytogenes was 15/36 $(41.7 \%)$ in the liver, $10 / 36(27.8 \%)$ in the breast, and $11 / 36(30.5 \%)$ in the thigh samples.

Our results were in agreement with Elmali et al. [52], who found a 37.5\% prevalence of L. monocytogenes in 120 retail poultry meat samples. Additionally, Ceylan et al. [53] reported similar results and found that $32.76 \%$ prevalence of L. monocytogenes was found in 38 of 116 analyzed samples. Escudero-Gilete et al. [54] reported 26\% prevalence in the retailed chicken meat samples. However, Goh et al. [55] found that L. monocytogenes was detected in $20 \%$ of the collected samples, and the prevalence of L. monocytogenes was relatively high in the breast meat samples (42.03\%) followed by drumstick (11.27\%) and thigh meat samples $(7.14 \%)$. As a result, the high prevalence of L. monocytogenes in fresh retail chicken meat, possibly due to poor sanitary quality control, may cause a risk to human health.

\subsection{L. monocytogenes Drug Resistance and Their Drug Resistance Patterns}

In our study, the susceptibility of $78 \mathrm{~L}$. monocytogenes isolates to 14 antimicrobial agents is listed in Table 1. The resistance of L. monocytogenes isolates against ERY, GEN, and TET was $61.5,73.1$, and $61.5 \%$, respectively. However, $66.7 \%$ of $L$. monocytogenes isolates showed susceptibility to AMP and VAN. Moreover, the susceptibility to RIF, CHL, and IPM was $64.1,60.3$, and $60.3 \%$, respectively. The minimum effectiveness was revealed by CIP, CLI, LNZ, NAL, OXA, and TMP that presented susceptibility ranged from 30.8 to $56.4 \%$ of all $L$. monocytogenes strains.

The resistance profile of each L. monocytogenes isolate was presented in Supplementary Materials, Figure S1. The clustering analysis of these strains was carried out to select the MDR L. monocytogenes isolates. Fifty isolates (64.1\%) were categorized as MDR L. monocytogenes, and their MAR indices ranged from 0.0 to 0.93 , with an average of 0.43 . The MAR index higher than 0.14 in our study referred to the tested L. monocytogenes strains originated from a high-risk source where antimicrobial agents are commonly used [56].

As shown in Table 2, drug resistance patterns (DRPs) obtained from the MDR strains were listed in 18 different DRPs. The most common DRPs were P1, P7, P5, and P5a, which included 18 isolates. However, P1a, P1b, P1c, and P3c included 12 isolates. These eight patterns included 60\% (30/50) of all tested MDR strains. As a result, one MDR $L$. monocytogenes strain was chosen randomly from each DRP for further investigation.

Mpondo et al. [57] reported that Listeria spp. were found to have phenotypic resistance to erythromycin, sulfonamides, chloramphenicol, aminoglycosides, $\beta$-lactams, streptomycin, and tetracycline. As a result, antibiotic-resistant Listeria has emerged as a growing One Health concern, exacerbating the worldwide antibiotic resistance crisis and weakening gains in healthcare, food production, and life expectancy, while posing health concerns to the environment, humans, and animals. Olaimat et al. [58] stated that antibiotic resistance of L. monocytogenes isolated from food frequently utilized in the treatment of human listeriosis, such as gentamicin, ampicillin, and tetracycline, had been reported. According to Teuber [59], L. monocytogenes is susceptible to a wide variety of drugs with antibacterial effects against Gram-positive bacteria, such as ampicillin, gentamicin, erythromycin, and tetracyclines. However, most of the L. monocytogenes strains were resistant to cefepime, fosfomycin, cefotaxime, lincosamides, and oxacillin [60]. Additionally, our findings were similar to Bouymajane et al. [6], who found that most L. monocytogenes strains 
originating from different food samples were resistant to tetracycline (20.0\%), ampicillin, and sulfamethoxazole/trimethoprim $(33.0 \%)$, sulfamethoxazole $(40.0 \%)$, erythromycin $(60.0 \%)$, and amoxicillin/clavulanic acid (67.0\%). They also found that MDR strains represented $66.7 \%$ of all isolated strains. Furthermore, vancomycin, rifampicin, and linezolid have been reported as effective agents in listerial infection disease [61]. Additionally, it has been proposed that rifampicin, considered effective against intracellular L. monocytogenes and may permeate the cerebrospinal fluid, could aid in the elimination of remaining bacteria [62].

Table 2. The antimicrobial resistance patterns of MDR L. monocytogens strains $(n=50)$.

\begin{tabular}{cccc}
\hline Pattern Code. & Antimicrobial Resistance Pattern & MAR Index & Strains No. \\
\hline P1 & W, X, Y, AMP, OXA, TET, TMP & 0.93 & 5 \\
P1a & X, Y, Z, AMP, LNZ, NAL, OXA & 0.93 & 3 \\
P1b & W, X, Y, Z, AMP & 0.93 & 3 \\
P1c & W, X, Y, Z, OXA & 0.93 & 3 \\
P2 & X, Y, LNZ, NAL, TET & 0.64 & 2 \\
P3 & Y, Z, AMP, CLI & 0.57 & 2 \\
P3a & XMP, CHL, CLI, IPM, NAL, RIF, TET, VAN & 0.57 & 1 \\
P3b & W, Y, CHL, CIP & 0.57 & 2 \\
P3c & I, AMP, CLI, Y, NAL & 0.57 & 3 \\
P4 & AMP, CIP, IPM, OXA, RIF, TMP, VAN & 0.50 & 2 \\
P4a & AMP, CLI, IPM, NAL, RIF, TET, VAN & 0.50 & 2 \\
P4b & CIP, CLI, ERY, GEN, LNZ, TET, VAN & 0.50 & 2 \\
P4 & CHL, ERY, GEN, NAL, OXA, TET & 0.50 & 2 \\
P5a & ERY, GEN, LNZ, OXA, TET, TMP & 0.43 & 4 \\
P6 & ERY, GEN, LNZ, TET, TMP & 0.43 & 4 \\
P7 & GEN, OXA, TET, TMP & 0.36 & 5 \\
P8 & CHL, ERY, GEN & 0.29 & 2 \\
\hline
\end{tabular}

W: NAL, LNZ, RIF; X: CHL, CIP, CLI; Y: ERY, GEN, IPM; Z: TET, TMP, VAN.

Currently, antibiotic resistance has developed in L. monocytogenes isolated from the environment and foods, notably for antibiotics frequently used to treat listeriosis. As a result of the evolution of resistant strains, it is essential to monitor changes in the antibiotic resistance of $L$. monocytogenes. In this context, our results were different than those reported by Chen et al. [63], who found that none of the 72 L. monocytogenes strains isolated from the aquatic product was MDR strain. Therefore, we can conclude that the acquired resistance against antimicrobial agents varies based on the bacterial habitat and environment.

\subsection{Drug Resistance Genes and Virulence Factors}

The incidence of genes associated with the drug resistance described was investigated. As a result, the frequency of antibiotic resistance-encoding genes was detected (Figure S2). Out of $18 \mathrm{MDR}$ L. monocytogenes selected isolates, the incidence of erm $\mathrm{B}$ and aadA genes was $72 \%(13 / 18)$ and $67 \%(6 / 18)$, respectively. The incidence of pen $\mathrm{A}$ and $f l o \mathrm{R}$ genes was $61 \%$ $(11 / 18)$ for each gene. However, $c m l \mathrm{~A}$, ere $\mathrm{A}$, and ere $\mathrm{B}$ express $44 \%(8 / 18)$ for each gene, and $\operatorname{amp} \mathrm{C}, \operatorname{van} \mathrm{A}, \operatorname{van} \mathrm{B}, \operatorname{tet} \mathrm{A}$, and tet $\mathrm{B}$ incidence was $33 \%(6 / 18), 33 \%(6 / 18), 39 \%(7 / 18), 28 \%$ $(5 / 18)$, and $28 \%(5 / 18)$, respectively. Similar results were reported by Srinivasan et al. [64], who investigated the presence of resistance genes of L. monocytogenes isolated from the dairy farms and found a high presence of floR, penA, tetA, strA, and sulI. Additionally, resistance genes for different antibiotic classes are frequently found on the same plasmid. Moreover, as shown in Supplementary Materials, Figure S2, inlA, prf A, plcB, and $a c t a \mathrm{~A}$ were the most prevalent genes in MDR isolates representing 94.4\% (17/18), 88.9\% (16/18), $83.3 \%(15 / 18)$, and $83.3 \%(15 / 18)$, respectively. The incidence of resistance genes showed that $h l y \mathrm{~A}, p l c \mathrm{~A}$, and inlJ genes were $77.8 \%(12 / 18)$. However, fla $\mathrm{A}$, lap, inlB, and inlC incidence was $72.2 \%(13 / 18), 66.7 \%$ (12/18), 56.6\% (10/18), And 61.1\% (11/18), respectively. 
Van Stelten et al. [65] found that a large proportion of L. monocytogenes isolated from food production sources showed a low pathogenicity. However, our results showed that all tested L. monocytogenes strains harbor at least $63 \%$ of tested virulence genes, which reflect their high pathogenicity. Our results were in agreement with Rugna et al. [66], who found that all investigated L. monocytogenes strains had all tested virulence genes. Shen et al. [67] reported that the incidence of inl $\mathrm{C}$ and inlJ increases the pathogenicity of L. monocytogenes virulence factors. Therefore, our results suggest that $L$. monocytogenes strains originating from food are potentially virulent and could have an essential role in epidemics, regardless of their source.

\subsection{L. monocytogenes Biofilm-Forming Ability}

As shown in Supplementary Material, Figure S2, among all selected L. monocytogenes strains, $88.9 \%(16 / 18)$ have the ability to form biofilm. Of those, $44.4 \%(8 / 18)$ of MDR strains showed strong biofilm formation ability with MPA $\left(\mathrm{OD}_{600}\right)$, ranging from 0.11 to 0.48 , while $22.2 \%$ (4/18) showed moderate biofilm-forming ability with MPA (OD 600$)$, ranging from 0.17 to 0.19 . However, $33.3 \%(6 / 18)$ showed a weak ability to form a biofilm with MPA $\left(\mathrm{OD}_{600}\right) \leq 0.1$.

L. monocytogenes can form biofilms as a strategy to survive in food processing environments because cells in biofilms typically exhibit increased tolerance against antimicrobial agents in comparison with their planktonic counterparts [68]. The colonization of L. monocytogenes on the surfaces of food processing equipment is enabled by the attachment and production of biofilm [69]. However, the presence of different virulence factor genes such as prf $\mathrm{A}$ and $h l y$ is essential for effective biofilm formation by L. monocytogenes [70].

In our study, the presence of adhesion protein (lap) and internalin proteins (inlA, inlB, $i n l C$, and inlJ) was observed in all strong biofilm-forming strains. Similarly, the occurrence of strong BFA in two isolates could be attributed to interruption or overexpression of biofilm-related genes [71].

In this study, among all tested MDR L. monocytogenes (18 isolates), five isolates had the maximum number of tested resistance and virulence genes. In addition to their ability to form biofilm was arranged into a cluster $X$, as shown in Figure 2. Identification and creation of a phylogenetic tree of the selected isolates were carried out using $16 \mathrm{~S}$ rRNA gene sequencing (Figure 3). CML-32, CML-51, CML-61, and CML-74 showed 100\% identity to Listeria monocytogenes 2016TE2013 (CP028392), Listeria monocytogenes Lm16 (CP027029), Listeria monocytogenes SLCC2479, serotype 3c (FR733649) and Listeria monocytogenes 08-7362 (CP008765), respectively. However, CML-20 showed an identity of 99.78 with Listeria monocytogenes SLCC5850 serotype 1/2a (FR733647). 


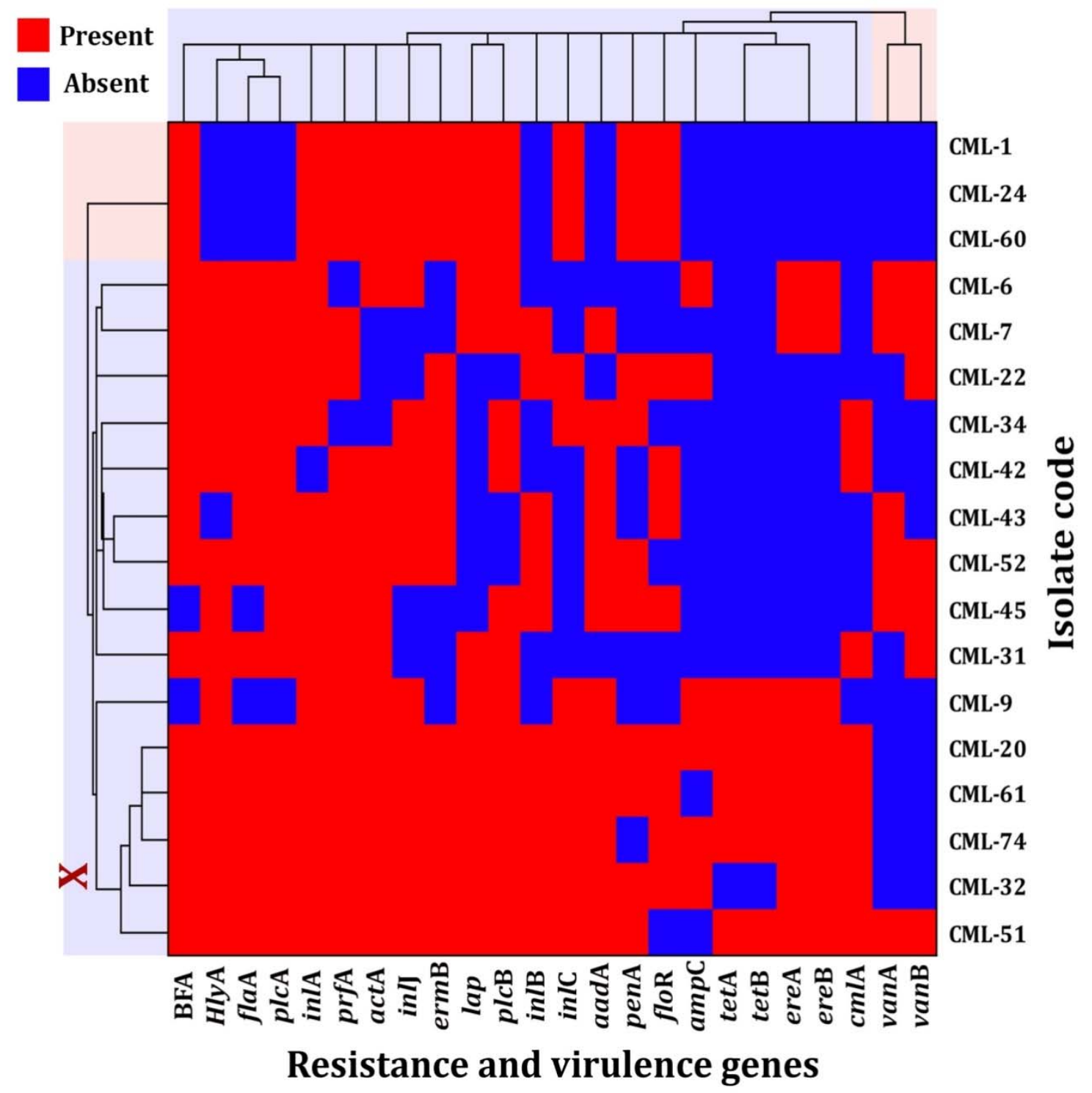

Figure 2. Clustering analysis of resistance and virulence genes-producing MDR L. monocytogenes strains: plcA, plcB, prf $\mathrm{A}$, and $a c t \mathrm{~A}, \mathrm{LIPI}-1$ pathogenicity island; $i n l \mathrm{~A}, i n l \mathrm{~B}, i n l \mathrm{C}$, and $i n l J$, internalin proteins; lap, adhesion protein; hly A, listeriolysin $\mathrm{O}$ gene, fla $\mathrm{A}$, flagellin protein; aad $\mathrm{A}$, aminoglycoside adenyltransferase; amp $\mathrm{C}$, $\beta$-lactamase-ampicillin resistance gene; ere $\mathrm{A}$, ere $\mathrm{B}$, and $\operatorname{erm} \mathrm{B}$, erythromycin resistance genes; pen $\mathrm{A}$, penicillin-binding protein gene; flo $\mathrm{R}$, florfenicol export protein; $\mathrm{cml} \mathrm{A}$, chloramphenicol transporter nonenzymatic chloramphenicol-resistance protein; tet $\mathrm{A}$ and tet $\mathrm{B}$, tetracycline resistance genes; $\operatorname{van} \mathrm{A}$ and $\operatorname{van} \mathrm{B}$, vanillate o-demethylase oxygenase subunit; $\mathrm{BFA}$, biofilm-forming ability. 


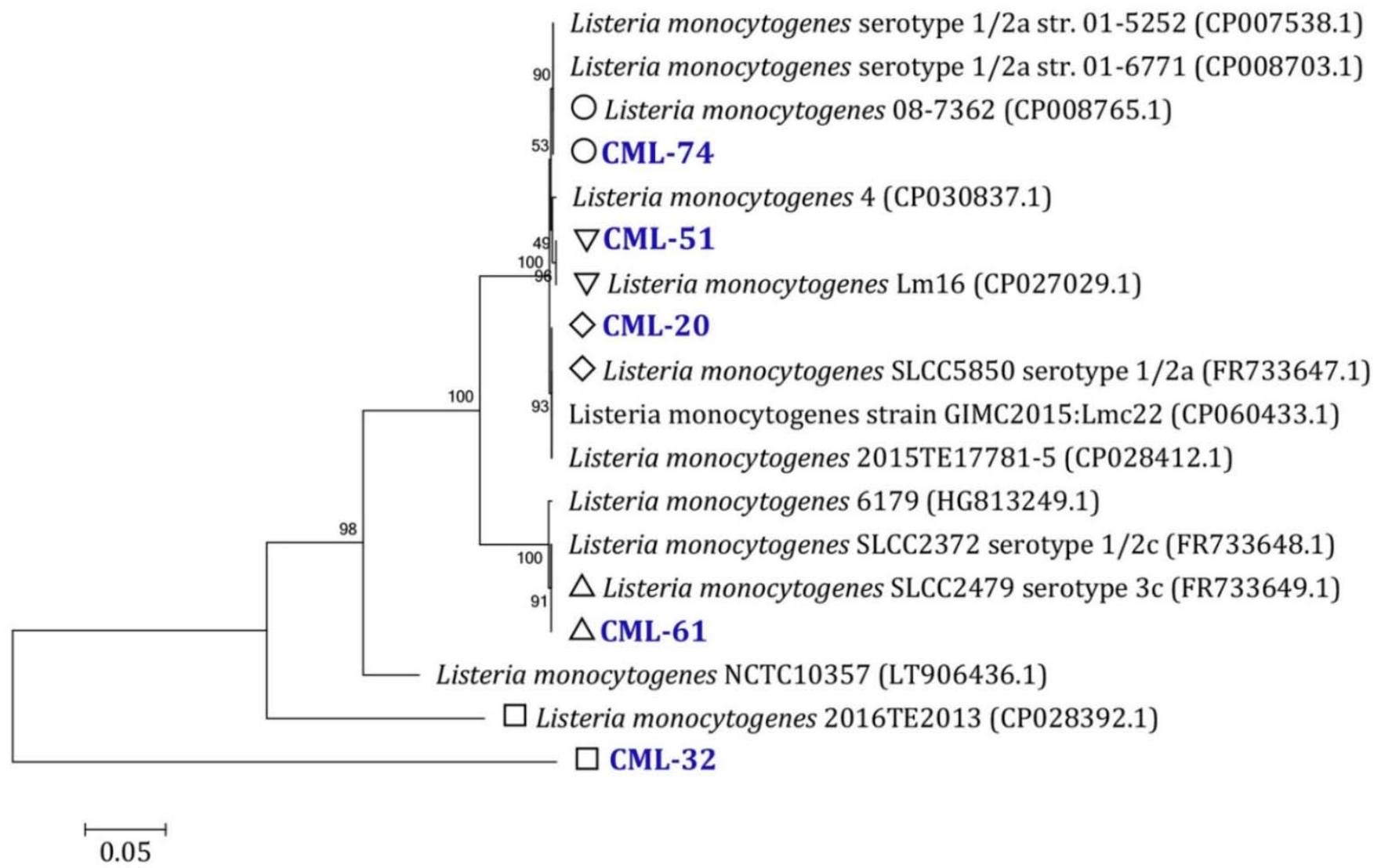

Figure 3. Neighbor-joining tree based on 16S rRNA gene sequences showing the placement of the phylogenetic position of the selected L. monocytogenes strains within closely related taxa. Bootstrap value ( $\geq 50 \%)$ derived from 1000 replicates.

\subsection{Essential Oil Antilisterial Activity}

The chemical composition analysis of the tested EOs are listed in Table 3, showing the main constituent content obtained from a peak area relative to the total peak area in GC-MS analysis. GC-MS analysis showed a high percentage of cinnamaldehyde (63.4\%), carvacrol $(67.2 \%), \gamma$-terpinene $(22.8 \%)$, geranyl acetate $(51.7 \%)$, linalool $(62.2 \%)$, linalyl acetate $(35.2 \%)$, and 1,8-cineole (28.5\%) in CBO, TWO, TRO, TGO, CRO, LTO, and RO, respectively.

Table 3. Essential oils used and their major constituents.

\begin{tabular}{|c|c|c|c|c|c|}
\hline No. & Essential Oil & Code & $\begin{array}{c}\text { Main } \\
\text { Constituent * }\end{array}$ & RT & $\begin{array}{c}\text { Content } \\
(\%)\end{array}$ \\
\hline \multirow[b]{2}{*}{1} & \multirow{2}{*}{ Cinnamon bark oil } & \multirow{2}{*}{$\mathrm{CBO}$} & Cinnamaldehyde & 29.79 & 63.4 \\
\hline & & & Cinnamyl acetate & 21.73 & 15.2 \\
\hline 2 & Thyme (wild) oil & TWO & Carvacrol & 18.09 & 67.2 \\
\hline \multirow{2}{*}{3} & \multirow{2}{*}{ Thyme (red) oil } & \multirow{2}{*}{$\mathrm{TRO}$} & Thymol & 21.02 & 17.4 \\
\hline & & & $\gamma$-terpinene & 10.11 & 22.8 \\
\hline \multirow[b]{2}{*}{4} & \multirow{2}{*}{ Thyme (geraniol) oil } & \multirow{2}{*}{ TGO } & Geraniol & 12.45 & 28.6 \\
\hline & & & Geranyl acetate & 16.33 & 51.7 \\
\hline 5 & Coriander oil & $\mathrm{CRO}$ & Linalool & 25.25 & 62.2 \\
\hline \multirow{2}{*}{6} & \multirow{2}{*}{ Lavender (true) oil } & \multirow{2}{*}{ LTO } & Linalool & 14.24 & 31.4 \\
\hline & & & Linalyl acetate & 17.41 & 35.2 \\
\hline \multirow{3}{*}{7} & \multirow{3}{*}{ Rosemary oil } & \multirow{3}{*}{$\mathrm{RO}$} & 1,8-cineole & 12.43 & 28.5 \\
\hline & & & $\alpha$-pinene & 7.07 & 19.3 \\
\hline & & & Camphor & 18.01 & 16.2 \\
\hline
\end{tabular}

* The main constituent content was detected from a peak area relative to the total peak area in GC-MS analysis The main constituents content higher than $15 \%$ are listed. 
The antibacterial activity of different EOs was investigated, as shown in Figure 4. Our results showed the efficiency of $\mathrm{CBO}$, TWO, and TRO as antilisterial agents. However, $\mathrm{CBO}$ was the most effective antibacterial agent against all resistance and virulence genesproducing MDR L. monocytogenes. The concentration of 0.5 and $0.25 \%$ showed a significant $(p<0.05)$ inhibitory effect against the selected strains for all tested EOs than 0.15 and $0.1 \%$. At $0.5 \%$, the inhibition zone ranged from $39.2 \mathrm{~mm}$ in CBO against CML-61 to $10.2 \mathrm{~mm}$ in LTO and RO against CML-20 and CML-51, respectively. At 0.25\%, the inhibition zone ranged from $32.7 \mathrm{~mm}$ in CBO against CML-61 to $9.1 \mathrm{~mm}$ in TGO against CML-61. However, at $0.15 \%$, the inhibition zone ranged from $26.2 \mathrm{~mm}$ in CBO against CML-32 to $6.5 \mathrm{~mm}$ in $\mathrm{RO}$ against $\mathrm{CML}-51$. At $0.1 \%$, the inhibition zone ranged from $24.0 \mathrm{~mm}$ in $\mathrm{CBO}$ against CML-61 to $6.2 \mathrm{~mm}$ in RO against CML-51. Therefore, the CBO, MIC, and MBC 90 values were detected, and our results showed that the MIC values varied from 0.25 to $0.5 \%(v / v)$ while $\mathrm{MBC}_{90}$ values ranged from 0.5 to $1.5 \%(v / v)$.

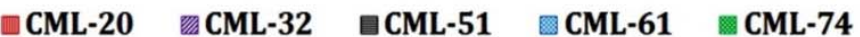
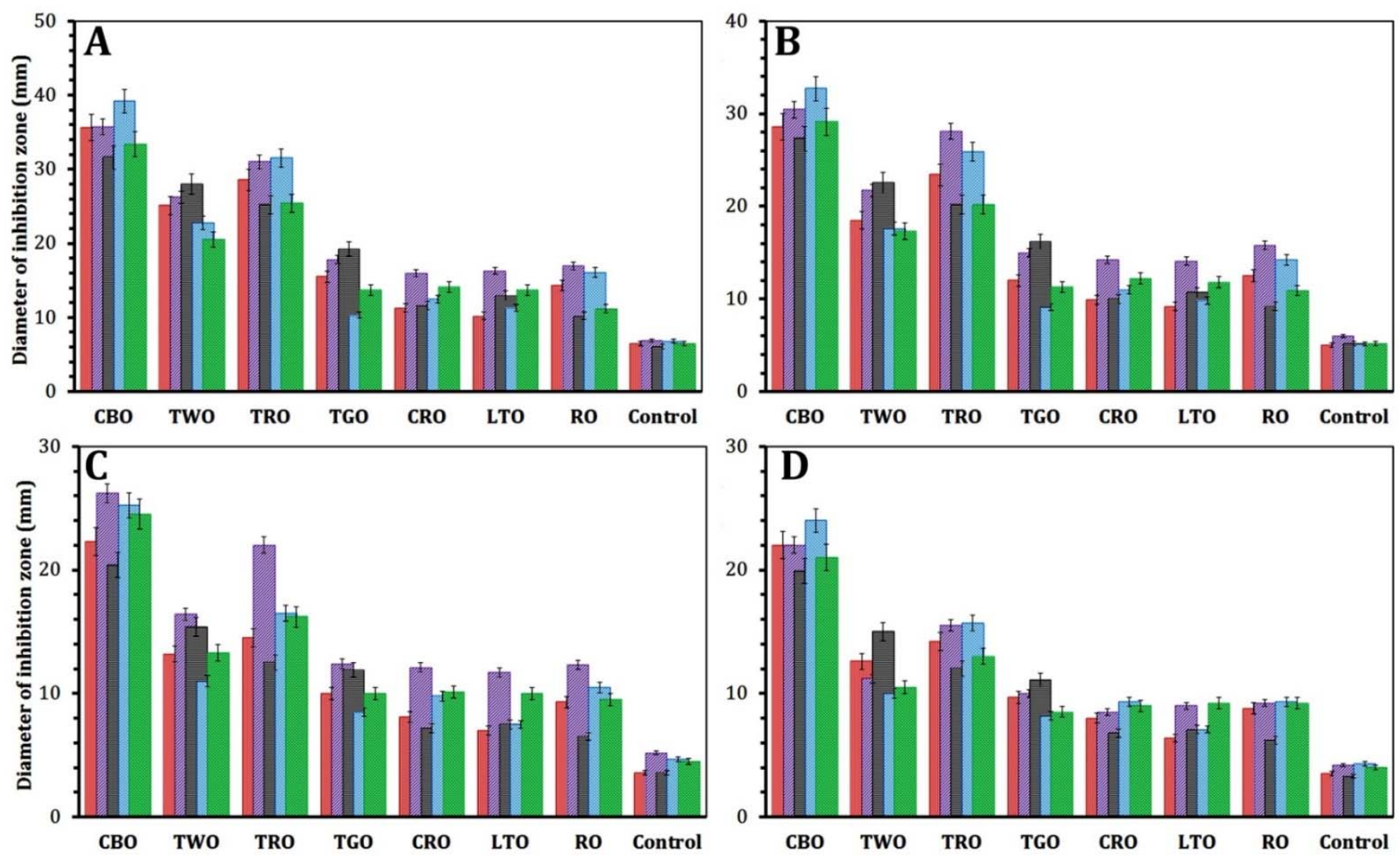

Figure 4. Antilisterial efficiency of different concentrations of essential oils against the selected L. monocytogenes strains: inhibitory effect at $0.5 \%(v / v)(\mathbf{A}), 0.25 \%(v / v)(\mathbf{B}), 0.15 \%(v / v)(\mathbf{C})$, and $0.1 \%(v / v)(\mathbf{D})$.

Our findings were in agreement with Hoque et al. [72], who reported that CBO reduced L. monocytogenes in ground chicken meat by $2.0 \mathrm{Log} \mathrm{CFU} / \mathrm{g}$ in one day. Additionally, Somrani et al. [15] showed that onion, garlic, and cinnamon essential oil were effective towards L. monocytogenes and are natural promising antimicrobial alternatives for food manufacture application. Additionally, Hussain et al. [16] stated that $0.025-0.05 \%$ of $\mathrm{CBO}$ addition was effective by stabilizing color and $\mathrm{pH}$ and retarding lipid oxidation through meat storage. The use of $0.5 \%$ of CBO leads to stability of color regardless of the bacteria growth reduction compared to other treatments. It can be suggested that adding $0.025 \%$ and $0.05 \%$ of $\mathrm{CBO}$ in meat can be considered as an option to sustain the quality of meat products. 


\section{6. $C B O$ Bioactivity as an Antilisterial Agent}

Because of the notable inhibitory effect of $\mathrm{CBO}$, the antilisterial mode of action of $\mathrm{CBO}$ against the selected L. monocytogenes strains was investigated using different techniques. As shown in Figure 5A, the viability of the bacterial cells decreased along with the incubation time compared to control. Our results also showed that the CML-61 strain was the most inhibited strain after $8 \mathrm{~h}$ of incubation due to the action of CBO followed by CML-20, CML-74, CML-32, and CML-51 with a bacterial count of $0.8 \pm 0.1,1.2 \pm 0.1,1.5 \pm 0.2$, and $2.6 \pm 0.4 \mathrm{Log} \mathrm{CFU} / \mathrm{mL}$, respectively.
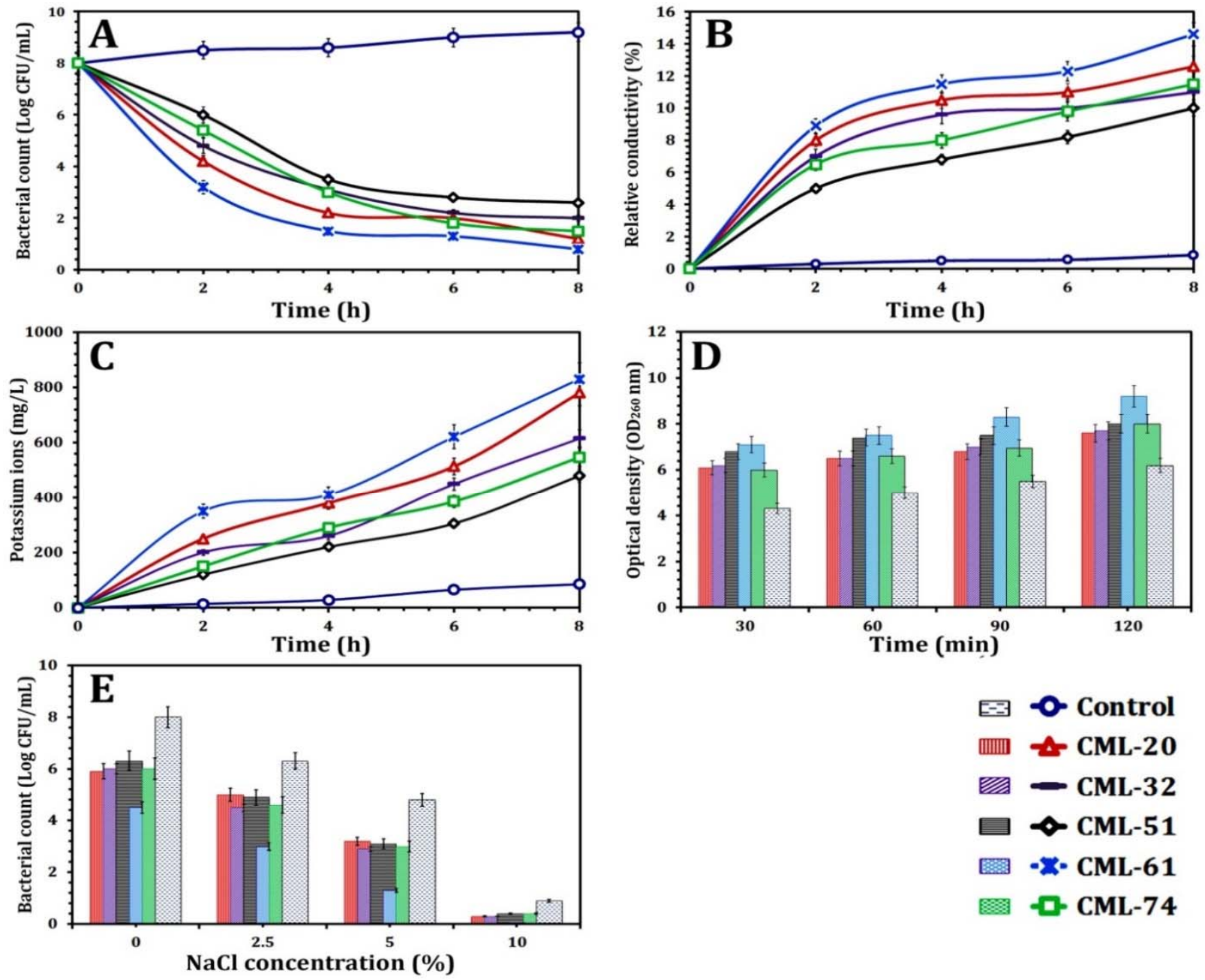

Figure 5. The antilisterial mechanism assays of cinnamon essential oil: (A) time-kill assay, (B) permeability of cell membrane, (C) leakage of potassium ions, (D) cell membrane integrity, and (E) loss of salt tolerance capacity.

Moreover, the relative electrical conductivity showed a rapid increase for all tested bacterial strains treated with $\mathrm{CBO}$, along with incubation time until the first $4 \mathrm{~h}$. As shown in Figure 5B, CML-61 showed the highest susceptibility to CBO with an increase in the relative conductivity $(14.6 \%)$ along with incubation time compared to control $(0.85 \%)$, followed by CML-20 (12.6\%), CML-74 (11.5\%), CML-32 (11.1\%), and CML-51 (10.1\%).

Additionally, the loss of $\mathrm{K}^{+}$ions from MDR L. monocytogenes tested strains treated with $\mathrm{CBO}$ confirms the concept that EOs acts by rupture and disrupts the bacterial cell membrane. After $8 \mathrm{~h}$ of incubation, a considerable increase indicated significant leakage of $\mathrm{K}^{+}$ions (Figure 5C). The concentration of $\mathrm{K}^{+}$ion reached $830 \pm 55,780 \pm 40,615 \pm 33,547$ \pm 44 , and $480 \pm 25 \mathrm{mg} / \mathrm{L}$ in cinnamon treated CML-61, CML-20, CML-51, CML-74 and CML-51, respectively. 
Concerning cell membrane integrity assay, the concentration of $260 \mathrm{~nm}$ absorbing materials was evaluated, as shown in Figure 5D. For 120 min of incubation, the concentration of $260 \mathrm{~nm}$ absorbing compounds in culture filtrates treated with CBO at the MIC concentration gradually increased for all tested strains. CML-61 was the most susceptible strain to $\mathrm{CBO}$ and showed a significantly $(p<0.05)$ higher absorbance $\left(\mathrm{OD}_{260 \mathrm{~nm}}=9.2\right)$ than control $\left(\mathrm{OD}_{260 \mathrm{~nm}}=6.2\right)$ and other L. monocytogenes strains after $60 \mathrm{~min}$. However, the other tested L. monocytogenes strains showed significant $(p<0.05)$ high absorbance than control, and insignificant variation was observed $(p>0.05)$.

Our study also revealed the effect of salt on L. monocytogenes cells treated with $\mathrm{CBO}$ at the MIC showed a gradual decline in viable cells number compared to the control sample. As shown in Figure 5E, there was insignificant variation $(p>0.05)$ in the bacterial count for CML-20, CML-32, CML-51, and CML-74 at different concentrations of $\mathrm{NaCl}$ and significant $(p<0.05)$ decrease in comparison with control. However, CML-61 showed significant decreases in comparison with other strains and control.

Due to the hydrophobic nature of cinnamaldehyde [13], it has the ability to penetrate the cytosol of treated bacterial cells easily because of the nature of Gram-positive bacterial membrane and leads to the rupture and damage of the cell membrane and consequently leads to cell lysis [73]. However, Cherrat et al. [14] investigated the effect of EOs on the viability of E. coli and Listeria innocua and reported that Gram-positive bacteria such as Listeria spp. are more susceptible to EOs than Gram-negative bacteria due to cell wall hydrophobic nature. Huang et al. [74] reported that CBO is an efficient agent towards foodborne pathogens by inhibiting microbes by various mechanisms such as rupture of the cell wall and the cytoplasmic membrane. Additionally, CBO causes leakage of cellular components, changes in fatty acid and phospholipid constituents, and inhibits protein translocation and genetic materials formation [75]. The significant leakage of cytosolic components was interpreted as an indicator of severe irreversible damage to the cell membrane [76]. Thus, ions and cell metabolites leakage from the CBO-treated bacterial cells could be effective as antilisterial activity. Patra and Baek [73] stated that the selectivity of the bacterial cell membrane plays a significant role in inhibiting the exiting of small ions such as $\mathrm{Ca}^{+2}, \mathrm{Na}^{+}$, and $\mathrm{K}^{+}$. This control of membrane permeability is critical to several cellular activities as cell maintenance, transport, and energy transduction. It is thought that cinnamaldehyde could cause abnormalities in the cell membrane, leading to $\mathrm{K}^{+}$leakage and resulting in cellular damage and lysis (Figure 6).

Moreover, the loss of listerial cells' ability to maintain their growth at a higher salt concentration demonstrates that EOs effects on the bacterial cell membrane led to membrane rupture and decreased the ability of osmoregulation through high salt stress. This impaired ability could potentially impact the membrane's performance to appropriately regulate the cell under excessive salt concentrations, resulting in cell death [73]. Therefore, our results were in agreement with Zhang et al. [77], who revealed that cinnamon oil caused small electrolyte leakage, resulting in a significant increase in the electric conductivity. Furthermore, the concentration of proteins and nucleic acids in cell suspension was proportional related to cinnamon oil concentration. Additionally, they found that Gram-positive bacteria were more sensitive to cinnamon oil than Gram-negative bacteria. As well, Vasconcelos et al. [78] reported that cinnamon oils and their compounds had been reported to inhibit bacteria by damaging the cell membrane; altering the lipid profile, membrane porins, motility; inhibiting ATPases, cell division, and biofilm formation, and antiquorum sensing effects.

In particular, concerning the food safety applications, Chen et al. [79] reported that cinnamaldehyde is a hydrophobic aromatic aldehyde that has been approved by the FAO/WHO Expert Committee on Food Additives (JECFA) for use as a food flavoring agent. Moreover, Boughendjioua and Djeddi [80] reported that CBO physicochemical and organoleptic properties are very appreciated in perfumery and will be very coveted in the food, cosmetic, and pharmaceutical industry. Furthermore, Goñi et al. [81] and Ju et al. [12] found that $\mathrm{CBO}$ has an antimicrobial effect in baked foods without influencing the organoleptic properties. Chitosan films containing $\mathrm{CBO}$ has antimicrobial activity, 
keeping the natural organoleptic characteristics and extending the shelf life [82]. Generally, our results indicate the efficiency of the antilisterial activity of cinnamaldehyde toward resistance and virulence genes-producing MDR L. monocytogenes strains, maintaining good nutritional and organoleptic properties of food products.

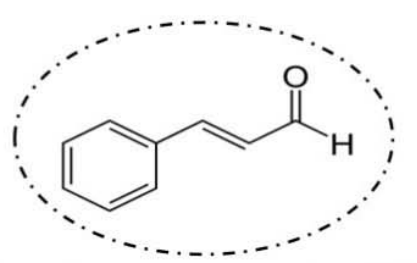

Bioactive components of CBO (cinnamaldehyde)

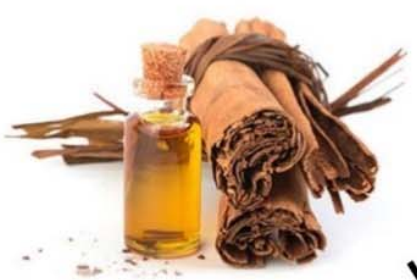

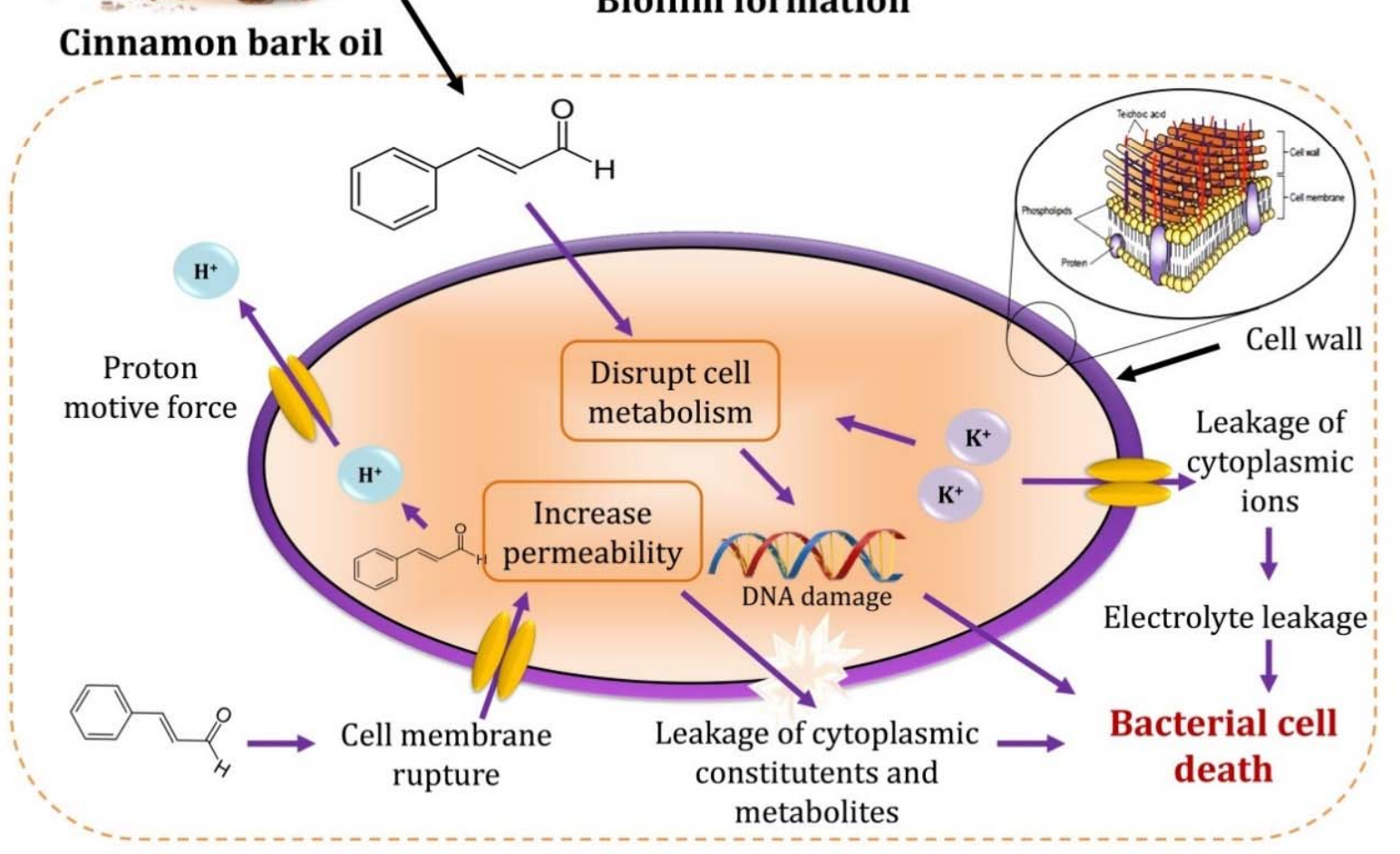
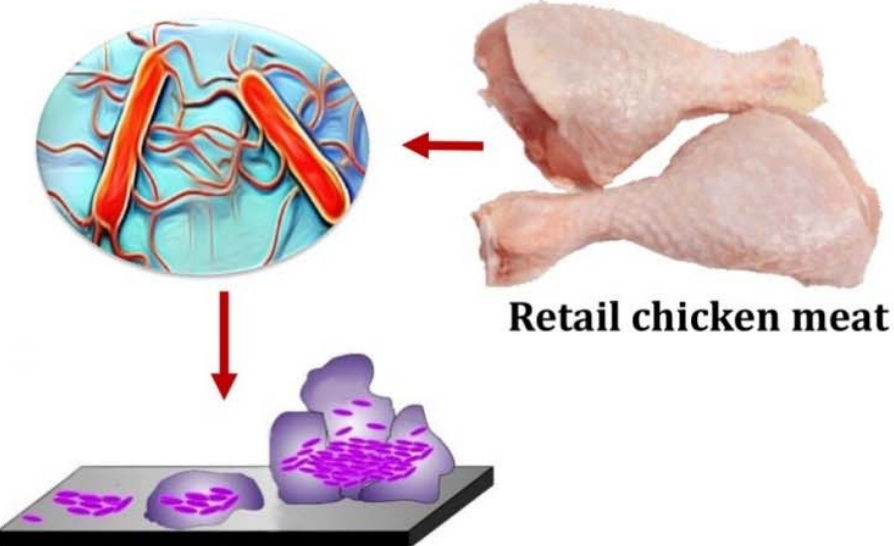

Biofilm formation

Figure 6. Proposed antibacterial mechanism of cinnamon essential oil against L. monocytogenes.

\section{Conclusions}

Listeria monocytogenes is one of the most severe foodborne pathogens. Our results revealed that the prevalence of $L$. monocytogenes in raw chicken meat in Zagazig city was $48 \%$. Seventy-eight isolates were identified as L. monocytogenes. Of those, $64.1 \%$ of the identified isolates were multidrug resistance bacteria. Moreover, the study of resistance genes on the selected isolate showed that $\operatorname{erm} \mathrm{B}, \operatorname{aad} \mathrm{A}, p e n \mathrm{~A}$, and $f l o \mathrm{R}$ genes were the most prevalent genes. However, the most prevalent virulence genes were inlA, prf A, $p l c \mathrm{~B}$, and $a c t a \mathrm{~A}$ genes. On the other hand, the activity of seven different essential oils against MDR L. monocytogenes was investigated. Cinnamon bark oil showed high efficiency as an antilisterial agent against MDR L. monocytogenes isolated from retail chicken meat. Our results also interpret cinnamon bark oil bioactivity by disrupting the cell membrane 
leading to a loss of membrane permeability, leakage of the cytoplasm constituents, ions, and metabolites. Therefore, this study could assist in detecting one of the promising antilisterial agents from natural sources that inhibits resistance and virulence genes-producing $L$. monocytogenes, which would improve food safety applications.

Supplementary Materials: The following are available online at https: / www.mdpi.com/article / 10.3390/foods10123006/s1, Figure S1: Clustering analysis for selecting the MDR L. monocytogenes strains., Figure S2. Incidence of resistance and virulence gene in MDR L. monocytogenes strains. Table S1: Antimicrobial agents, zone and interpretive chart., Table S2. PCR Primers and references for 16S rRNA of L. monocytogens and virulence genes., Table S3. PCR Primers and references for 16S rRNA of Listeria and virulence genes.

Author Contributions: Conceptualization, A.E.M.A.M. and M.A.H.; methodology, A.K.E. and M.A.H.; validation, A.E.M.A.M. and M.A.H. and M.T.E.; formal analysis, A.K.E. and M.E.M.M.; investigation, M.E.M.M.; writing—original draft preparation, A.K.E.; writing-review and editing, A.K.E. and M.S.A.-M.; visualization, M.E.M.M.; supervision, A.E.M.A.M. and M.A.H.; funding acquisition, M.S.A.-M. All authors have read and agreed to the published version of the manuscript.

Funding: This research was funded by the Scientific Research Deanship at University of Ha'il, SaudiArabia through project number RG-20 200.

Institutional Review Board Statement: Not applicable.

Informed Consent Statement: Not applicable.

Data Availability Statement: The datasets generated and/or analyzed during the current study areavailable from the corresponding author on reasonable request.

Acknowledgments: This research has been funded by the Scientific Research Deanship at University of Háil, Saudi Arabia, through project number RG-20 200. The Microbiology Laboratory of Molecular Diagnostic and Personalized Therapeutics Unit (MDXPTU), University of Háil, Saudi Arabia, is acknowledged for its support.

Conflicts of Interest: The authors declare that they have no conflict of interest.

\section{References}

1. Farber, J.M.; Zwietering, M.; Wiedmann, M.; Schaffner, D.; Hedberg, C.W.; Harrison, M.A.; Hartnett, E.; Chapman, B.; Donnelly, C.W.; Goodburn, K.E.; et al. Alternative approaches to the risk management of Listeria monocytogenes in low risk foods. Food Control 2021, 123, 107601. [CrossRef]

2. Yu, H.; Guo, W.; Lu, X.; Xu, H.; Yang, Q.; Tan, J.; Zhang, W. Reduced graphene oxide nanocomposite based electrochemical biosensors for monitoring foodborne pathogenic bacteria: A review. Food Control 2021, 127, 108117. [CrossRef]

3. Radoshevich, L.; Cossart, P. Listeria monocytogenes: Towards a complete picture of Its physiology and pathogenesis. Nat. Rev. Microbiol. 2017, 16, 32-46. [CrossRef]

4. Huang, Y.-T.; Kuo, Y.-W.; Lee, M.-R.; Tsai, Y.-H.; Teng, L.-J.; Tsai, M.-S.; Liao, C.-H.; Hsueh, P.-R. Clinical and molecular epidemiology of human listeriosis in Taiwan. Int. J. Infect. Dis. 2021, 104, 718-724. [CrossRef]

5. Ghosh, P.; Halvorsen, E.M.; Ammendolia, D.A.; Mor-Vaknin, N.; O’Riordan, M.X.D.; Brumell, J.H.; Markovitz, D.M.; Higgins, D.E. Invasion of the brain by Listeria monocytogenes is mediated by InlF and host cell Vimentin. MBio 2018, 9, e00160-18. [CrossRef]

6. Bouymajane, A.; Rhazi Filali, F.; Oulghazi, S.; Lafkih, N.; Ed-Dra, A.; Aboulkacem, A.; El Allaoui, A.; Ouhmidou, B.; Moumni, M. Occurrence, antimicrobial resistance, serotyping and virulence genes of Listeria monocytogenes Isolated from foods. Heliyon 2021, 7, e06169. [CrossRef] [PubMed]

7. Barreca, S.; La Bella, S.; Maggio, A.; Licata, M.; Buscemi, S.; Leto, C.; Pace, A.; Tuttolomondo, T. Flavouring extra-virgin olive oil with aromatic and medicinal plants essential oils stabilizes oleic acid composition during photo-oxidative stress. Agriculture 2021, 11, 266. [CrossRef]

8. Puvača, N.; Milenković, J.; Galonja Coghill, T.; Bursić, V.; Petrović, A.; Tanasković, S.; Pelić, M.; Ljubojević Pelić, D.; Miljković, T. Antimicrobial activity of selected essential oils against selected pathogenic bacteria: In vitro study. Antibiotics 2021, 10, 546. [CrossRef]

9. Andrade-Ochoa, S.; Chacón-Vargas, K.F.; Sánchez-Torres, L.E.; Rivera-Chavira, B.E.; Nogueda-Torres, B.; Nevárez-Moorillón, G.V. Differential antimicrobial effect of essential oils and their main components: Insights based on the cell membrane and external structure. Membranes 2021, 11, 405. [CrossRef]

10. Gyawali, R.; Ibrahim, S.A. Natural products as antimicrobial agents. Food Control 2014, 46, 412-429. [CrossRef]

11. Negi, P.S. Plant extracts for the control of bacterial growth: Efficacy, stability and safety issues for food application. Int. J. Food Microbiol. 2012, 156, 7-17. [CrossRef] 
12. Ju, J.; Xu, X.; Xie, Y.; Guo, Y.; Cheng, Y.; Qian, H.; Yao, W. Inhibitory effects of cinnamon and clove essential oils on mold growth on baked foods. Food Chem. 2018, 240, 850-855. [CrossRef] [PubMed]

13. Rao, P.J.; Sowbhagya, H.B. Nanoencapsulation of Spice Oils. In Handbook of Food Bioengineering, Soft Chemistry and Food Fermentation; Academic Press: Cambridge, MA, USA, 2017; pp. 179-207. [CrossRef]

14. Cherrat, L.; Dumas, E.; Bakkali, M.; Degraeve, P.; Laglaoui, A.; Oulahal, N. Effect of essential oils on cell viability, membrane integrity and membrane fluidity of listeria innocua and Escherichia coli. J. Essent. Oil Bear. Plants 2016, 19, 155-166. [CrossRef]

15. Somrani, M.; Inglés, M.-C.; Debbabi, H.; Abidi, F.; Palop, A. Garlic, onion, and cinnamon essential oil anti-biofilms' effect against Listeria monocytogenes. Foods 2020, 9, 567. [CrossRef]

16. Hussain, Z.; Li, X.; Zhang, D.; Hou, C.; Ijaz, M.; Bai, Y.; Xiao, X.; Zheng, X. Influence of adding cinnamon bark oil on meat quality of ground lamb during storage at $4{ }^{\circ} \mathrm{C}$. Meat Sci. 2021, 171, 108269. [CrossRef]

17. Mellado-García, P.; Puerto, M.; Pichardo, S.; Llana-Ruiz-Cabello, M.; Moyano, R.; Blanco, A.; Jos, A.; Cameán, A.M. Toxicological evaluation of an allium-based commercial product in a 90-day feeding study in sprague-dawley rats. Food Chem. Toxicol. 2016, 90, 18-29. [CrossRef]

18. Ariza, J.J.; García-López, D.; Sánchez-Nieto, E.; Guillamón, E.; Baños, A.; Martínez-Bueno, M. Antilisterial effect of a natural formulation based on citrus extract in ready-to-eat foods. Foods 2021, 10, 1475. [CrossRef]

19. Cock, I.E.; Van Vuuren, S.F. The traditional use of Southern African medicinal plants in the treatment of viral respiratory diseases: A review of the ethnobotany and scientific evaluations. J. Ethnopharmacol. 2020, 262, 113194. [CrossRef]

20. British Standards Institution (BSI). BS EN ISO 11290-2 Microbiology of Food and Animal Feeding Stuffs \pm Horizontal Method for the Detection and Enumeration of Listeria monocytogenes-Part 2: Enumeration Method; BSI: London, UK, 1998. [CrossRef]

21. Seeliger, H.P.; Jones, D. Listeria. In Bergey's Manual of Systematic Bacteriology; Sneath, P.H.A., Nair, N.S., Sharpe, N.E., Holt, J.G., Eds.; Williams and Wilkins: Baltimore, MD, USA, 1986; pp. 1235-1245.

22. Honjoh, K.; Fujihara, K.; Haraguchi, T.; Ono, Y.; Kobayashi, H.; Hiwaki, H.; Kamikado, H.; Jang, S.S.; Ryu, S.; Miyamoto, T. Subtyping of Listeria monocytogenes based on nucleotide polymorphism in the ClpC, InlA, HlyA, and PlcA genes and rapid identification of L. monocytogenes genetically similar to clinical isolates. Food Sci. Technol. Res. 2008, 14, 557-564. [CrossRef]

23. Morvan, A.; Moubareck, C.; Leclercq, A.; Hervé-Bazin, M.; Bremont, S.; Lecuit, M.; Courvalin, P.; Le Monnier, A. Antimicrobial resistance of Listeria monocytogenes strains isolated from humans in France. Antimicrob. Agents Chemother. 2010, 54, $2728-2731$. [CrossRef] [PubMed]

24. Clinical and Laboratory Standards Institute (CLSI). Performance Standards for Antimicrobial Susceptibility Testing, CLSI Supplement M100, 27th ed.; Clinical Laboratory Standards Institute: Wayne, NJ, USA, 2017; pp. 15-20. [CrossRef]

25. Odjadjare, E.E.O.; Obi, L.C.; Okoh, A.I. Municipal wastewater effluents as a source of Listerial pathogens in the aquatic milieu of the Eastern Cape province of South Africa: A concern of public health importance. Int. J. Environ. Res. Public Health 2010, 7 , 2376-2394. [CrossRef]

26. Osundiya, O.O.; Oladele, R.O.; Oduyebo, O.O. Multiple antibiotic resistance (MAR) indices of Pseudomonas and Klebsiella species isolates in Lagos University Teaching Hospital. Afr. J. Clin. Exp. Microbiol. 2013, 14, 164-168. [CrossRef]

27. Osman, K.M.; Samir, A.; Abo-Shama, U.H.; Mohamed, E.H.; Orabi, A.; Zolnikov, T. Determination of virulence and antibiotic resistance pattern of biofilm producing Listeria species isolated from retail raw milk. BMC Microbiol. 2016, 16, 263. [CrossRef]

28. Vázquez-Boland, J.A.; Kuhn, M.; Berche, P.; Chakraborty, T.; Domínguez-Bernal, G.; Goebel, W.; González-Zorn, B.; Wehland, J.; Kreft, J. Listeria pathogenesis and molecular virulence determinants. Clin. Microbiol. Rev. 2001, 14, 584-640. [CrossRef]

29. Di Ciccio, P.; Meloni, D.; Festino, A.R.; Conter, M.; Zanardi, E.; Ghidini, S.; Vergara, A.; Mazzette, R.; Ianieri, A. Longitudinal study on the sources of Listeria monocytogenes contamination in cold-smoked salmon and its processing environment in Italy. Int. J. Food Microbiol. 2012, 158, 79-84. [CrossRef] [PubMed]

30. Gray, D.I.; Kroll, R.G. Polymerase chain reaction amplification of the FlaA gene for the rapid identification of Listeria spp. Lett. Appl. Microbiol. 1995, 20, 65-68. [CrossRef] [PubMed]

31. Furrer, B.; Candrian, U.; Hoefelein, C.; Luethy, J. Detection and identification of Listeria monocytogenes in cooked sausage products and in milk by in vitro amplification of haemolysin gene fragments. J. Appl. Bacteriol. 1991, 70, 372-379. [CrossRef]

32. Notermans, S.H.; Dufrenne, J.; Leimeister-Wächter, M.; Domann, E.; Chakraborty, T. Phosphatidylinositol-specific phospholipase $\mathrm{C}$ activity as a marker to distinguish between pathogenic and nonpathogenic Listeria species. Appl. Environ. Microbiol. 1991, 57, 2666-2670. [CrossRef]

33. Cooray, K.J.; Nishibori, T.; Xiong, H.; Matsuyama, T.; Fujita, M.; Mitsuyama, M. Detection of multiple virulence-associated genes of Listeria monocytogenes by PCR in artificially contaminated milk samples. Appl. Environ. Microbiol. 1994, 60, 3023-3026. [CrossRef] [PubMed]

34. Suarez, M.; Gonzalez-Zorn, B.; Vega, Y.; Chico-Calero, I.; Vazquez-Boland, J.-A. A Role for ActA in epithelial cell invasion by Listeria monocytogenes. Cell. Microbiol. 2001, 3, 853-864. [CrossRef]

35. Liu, D.; Lawrence, M.L.; Austin, F.W.; Ainsworth, A.J. A multiplex PCR for species-and virulence-specific determination of Listeria monocytogenes. J. Microbiol. Methods 2007, 71, 133-140. [CrossRef] [PubMed]

36. Zhang, W.E.I.; Knabel, S.J. Multiplex PCR assay simplifies serotyping and sequence typing of Listeria monocytogenes associated with human outbreaks. J. Food Prot. 2005, 68, 1907-1910. [CrossRef] [PubMed]

37. Lanz, R.; Kuhnert, P.; Boerlin, P. Antimicrobial resistance and resistance gene determinants in clinical Escherichia coli from different animal species in Switzerland. Vet. Microbiol. 2003, 91, 73-84. [CrossRef] 
38. Okamoto, K.; Gotoh, N.; Nishino, T. Extrusion of penem antibiotics by multicomponent efflux systems MexAB-OprM, MexCDOprJ, and MexXY-OprM of Pseudomonas Aeruginosa. Antimicrob. Agents Chemother. 2002, 46, 2696-2699. [CrossRef]

39. Antignac, A. Polymorphism of Neisseria meningitidis PenA gene associated with reduced susceptibility to Penicillin. J. Antimicrob. Chemother. 2001, 47, 285-296. [CrossRef]

40. Keyes, K.; Hudson, C.; Maurer, J.J.; Thayer, S.; White, D.G.; Lee, M.D. Detection of florfenicol resistance genes in Escherichia coli isolated from sick chickens. Antimicrob. Agents Chemother. 2000, 44, 421-424. [CrossRef] [PubMed]

41. Gebreyes, W.A.; Altier, C. Molecular characterization of multidrug-resistant Salmonella enterica subsp. Enterica serovar Typhimurium isolates from swine. J. Clin. Microbiol. 2002, 40, 2813-2822. [CrossRef] [PubMed]

42. Guillaume, G.; Verbrugge, D.; Chasseur-Libotte, M.-L.; Moens, W.; Collard, J.-M. PCR typing of tetracycline resistance determinants (Tet A-E) in Salmonella enterica serotype Hadar and in the microbial community of activated sludges from hospital and urban wastewater treatment facilities in Belgium. FEMS Microbiol. Ecol. 2000, 32, 77-85. [CrossRef] [PubMed]

43. Sutcliffe, J.; Tait-Kamradt, A.; Wondrack, L. Streptococcus pneumoniae and Streptococcus pyogenes resistant to Macrolides but sensitive to Clindamycin: A common resistance pattern mediated by an Efflux System. Antimicrob. Agents Chemother. 1996, 40, 1817-1824. [CrossRef]

44. Lee, B.-H.; Hébraud, M.; Bernardi, T. Increased adhesion of Listeria monocytogenes strains to abiotic surfaces under cold stress. Front. Microbiol. 2017, 8, 2221. [CrossRef]

45. Dudek-Wicher, R.; Paleczny, J.; Kowalska-Krochmal, B.; Szymczyk-Ziółkowska, P.; Pachura, N.; Szumny, A.; Brożyna, M. Activity of liquid and volatile fractions of essential oils against biofilm formed by selected reference strains on polystyrene and hydroxyapatite surfaces. Pathogens 2021, 10, 515. [CrossRef]

46. Diao, W.-R.; Hu, Q.-P.; Feng, S.-S.; Li, W.-Q.; Xu, J.-G. Chemical composition and antibacterial activity of the essential oil from green Huajiao (Zanthoxylum schinifolium) against selected foodborne pathogens. J. Agric. Food Chem. 2013, 61, 6044-6049. [CrossRef]

47. Li, Z.-H.; Cai, M.; Liu, Y.-S.; Sun, P.-L.; Luo, S.-L. Antibacterial activity and mechanisms of essential oil from Citrus medica L. Var. Sarcodactylis. Molecules 2019, 24, 1577. [CrossRef] [PubMed]

48. Ye, X.; Li, X.; Yuan, L.; He, H. Effect of the surface activity on the antibacterial activity of octadecanoyl acetal sodium sulfite series. Colloids Surf. A Physicochem. Eng. Asp. 2005, 268, 85-89. [CrossRef]

49. Bajpai, V.K.; Sharma, A.; Baek, K.-H. Antibacterial mode of action of Cudrania tricuspidata fruit essential oil, affecting membrane permeability and surface characteristics of food-borne pathogens. Food Control. 2013, 32, 582-590. [CrossRef]

50. Carson, C.F.; Mee, B.J.; Riley, T.V. Mechanism of action of Melaleuca alternifolia (Tea Tree) oil on staphylococcus aureus determined by time-kill, lysis, leakage, and salt tolerance assays and electron microscopy. Antimicrob. Agents Chemother. 2002, 46, 1914-1920. [CrossRef]

51. Miksusanti; Jenie, B. S.L.; Priosoeryanto, B.P.; Syarief, R.; Rekso, G.T. Mode of action Temu Kunci (Kaempferia pandurata) essential oil on E. Coli K1.1 cell determined by leakage of material cell and salt Tolerance assays. HAYATI J. Biosci. 2008, 15, 56-60. [CrossRef]

52. Elmali, M.; Can, H.Y.; Yaman, H. Prevalence of Listeria monocytogenes in poultry meat. Food Sci. Technol. 2015, 35, 672-675. [CrossRef]

53. Ceylan, Z.G.; Demirkaya, A.K.; Adigüzel, G. Incidence of Listeria monocytogenes in retail chicken meat and establishing relationship with some bacteria by logistic regression. J. Food Qual. 2008, 31, 121-130. [CrossRef]

54. Escudero-Gilete, M.L.; González-Miret, M.L.; Temprano, R.M.; Heredia, F.J. Application of a multivariate concentric method system for the location of Listeria monocytogenes in a poultry slaughterhouse. Food Control 2007, 18, 69-75. [CrossRef]

55. Goh, S.G.; Kuan, C.H.; Loo, Y.Y.; Chang, W.S.; Lye, Y.L.; Soopna, P.; Tang, J.Y.H.; Nakaguchi, Y.; Nishibuchi, M.; Afsah-Hejri, L.; et al. Listeria monocytogenes in retailed raw chicken meat in Malaysia. Poult. Sci. 2012, 91, 2686-2690. [CrossRef]

56. Gufe, C.; Canaan Hodobo, T.; Mbonjani, B.; Majonga, O.; Marumure, J.; Musari, S.; Jongi, G.; Makaya, P.V.; Machakwa, J. Antimicrobial profiling of bacteria isolated from fish sold at informal market in Mufakose, Zimbabwe. Int. J. Microbiol. 2019, 2019, 8759636. [CrossRef] [PubMed]

57. Mpondo, L.; Ebomah, K.E.; Okoh, A.I. Multidrug-resistant Listeria species shows abundance in environmental waters of a Key District municipality in South Africa. Int. J. Environ. Res. Public Health 2021, 18, 481. [CrossRef] [PubMed]

58. Olaimat, A.N.; Al-Holy, M.A.; Shahbaz, H.M.; Al-Nabulsi, A.A.; Abu Ghoush, M.H.; Osaili, T.M.; Ayyash, M.M.; Holley, R.A. Emergence of antibiotic resistance in Listeria monocytogenes isolated from food products: A comprehensive review. Compr. Rev. Food Sci. Food Saf. 2018, 17, 1277-1292. [CrossRef]

59. Teuber, M. Spread of antibiotic resistance with food-borne pathogens. Cell. Mol. Life Sci. 1999, 56, 755-763. [CrossRef] [PubMed]

60. Actualités et Perspectives 2014 Du Comité Antibiogramme de la Société Française de Microbiologie (CA-SFM). Option/Bio 2014, 25, 13. Available online: https://www.sciencedirect.com/science/article/abs/pii/S0992594514716411?via\%3Dihub (accessed on 1 September 2021). [CrossRef]

61. Morosi, S.; Francisci, D.; Baldelli, F. A case of Rhombencephalitis caused by Listeria monocytogenes successfully treated with linezolid. J. Infect. 2006, 52, e73-e75. [CrossRef] [PubMed]

62. Conter, M.; Paludi, D.; Zanardi, E.; Ghidini, S.; Vergara, A.; Ianieri, A. Characterization of antimicrobial resistance of foodborne Listeria monocytogenes. Int. J. Food Microbiol. 2009, 128, 497-500. [CrossRef] 
63. Chen, M.; Cheng, J.; Wu, Q.; Zhang, J.; Chen, Y.; Xue, L.; Lei, T.; Zeng, H.; Wu, S.; Ye, Q.; et al. Occurrence, antibiotic resistance, and population diversity of Listeria monocytogenes isolated from fresh aquatic products in China. Front. Microbiol. $2018,9,2215$. [CrossRef]

64. Srinivasan, V.; Nam, H.M.; Nguyen, L.T.; Tamilselvam, B.; Murinda, S.E.; Oliver, S.P. Prevalence of antimicrobial resistance genes In Listeria monocytogenes isolated from dairy farms. Foodborne Pathog. Dis. 2005, 2, 201-211. [CrossRef]

65. Van Stelten, A.; Roberts, A.R.; Manuel, C.S.; Nightingale, K.K. Listeria monocytogenes isolates carrying virulence-attenuating mutations in internalin A are commonly isolated from ready-to-eat food processing plant and retail environments. J. Food Prot. 2016, 79, 1733-1740. [CrossRef]

66. Rugna, G.; Carra, E.; Bergamini, F.; Franzini, G.; Faccini, S.; Gattuso, A.; Morganti, M.; Baldi, D.; Naldi, S.; Serraino, A.; et al. Distribution, virulence, genotypic characteristics and antibiotic resistance of Listeria monocytogenes isolated over one-year monitoring from two pig slaughterhouses and processing plants and their fresh hams. Int. J. Food Microbiol. 2021, $336,108912$. [CrossRef] [PubMed]

67. Shen, J.; Rump, L.; Zhang, Y.; Chen, Y.; Wang, X.; Meng, J. Molecular subtyping and virulence gene analysis of Listeria monocytogenes isolates from food. Food Microbiol. 2013, 35, 58-64. [CrossRef]

68. Pang, X.; Wong, C.; Chung, H.-J.; Yuk, H.-G. Biofilm formation of Listeria monocytogenes and its resistance to Quaternary ammonium compounds in a simulated salmon processing environment. Food Control 2019, 98, 200-208. [CrossRef]

69. Kumar, S.; Parvathi, A.; George, J.; Krohne, G.; Karunasagar, I.; Karunasagar, I. A study on the effects of some laboratory-derived genetic mutations on biofilm formation by Listeria monocytogenes. World J. Microbiol. Biotechnol. 2008, 25, 527-531. [CrossRef]

70. Price, R.; Jayeola, V.; Niedermeyer, J.; Parsons, C.; Kathariou, S. The Listeria monocytogenes key virulence determinants Hly and PrfA are involved in biofilm formation and Aggregation but not colonization of fresh produce. Pathogens 2018, 7, 18. [CrossRef]

71. Piercey, M.J.; Hingston, P.A.; Truelstrup Hansen, L. Genes involved in Listeria monocytogenes biofilm formation at a simulated food processing plant temperature of $15{ }^{\circ} \mathrm{C}$. Int. J. Food Microbiol. 2016, 223, 63-74. [CrossRef]

72. Mahfuzul Hoque, M.D.; Bari, M.L.; Inatsu, Y.; Juneja, V.K.; Kawamoto, S. Antibacterial activity of guava (Psidium guajava L.) and neem (Azadirachta indica A. Juss.) extracts against foodborne pathogens and spoilage bacteria. Foodborne Pathog. Dis. 2007, 4, 481-488. [CrossRef]

73. Patra, J.K.; Baek, K.-H. Anti-Listerial activity of four seaweed essential oils against Listeria monocytogenes. Jundishapur J. Microbiol. 2016, 9, e31784. [CrossRef]

74. Huang, S.; Liu, B.; Ge, D.; Dai, J. Effect of combined treatment with supercritical $\mathrm{CO}_{2}$ and rosemary on microbiological and physicochemical properties of ground pork stored at $4{ }^{\circ} \mathrm{C}$. Meat Sci. 2017, 125, 114-120. [CrossRef]

75. Bajpai, V.K.; Sharma, A.; Baek, K.-H. Antibacterial mechanism of action of taxus cuspidata stem essential oil against selected foodborne pathogens. J. Food Saf. 2013, 33, 348-359. [CrossRef]

76. Zhou, K.; Zhou, W.; Li, P.; Liu, G.; Zhang, J.; Dai, Y. Mode of action of Pentocin 31-1: An antilisteria bacteriocin produced by Lactobacillus Pentosus from Chinese traditional ham. Food Control 2008, 19, 817-822. [CrossRef]

77. Zhang, Y.; Liu, X.; Wang, Y.; Jiang, P.; Quek, S. Antibacterial activity and mechanism of cinnamon essential oil against Escherichia Coli and Staphylococcus aureus. Food Control 2016, 59, 282-289. [CrossRef]

78. Vasconcelos, N.G.; Croda, J.; Simionatto, S. Antibacterial mechanisms of cinnamon and its constituents: A review. Microb. Pathog. 2018, 120, 198-203. [CrossRef]

79. Chen, E.; Wu, S.; McClements, D.J.; Li, B.; Li, Y. Influence of PH and Cinnamaldehyde on the physical stability and lipolysis of whey protein isolate-stabilized emulsions. Food Hydrocoll. 2017, 69, 103-110. [CrossRef]

80. Boughendjioua, H.; Djeddi, S. Study of the organoleptic and physicochemical properties of cinnamon essential oil (Cinnamomum zeylanicum). Am. J. Life Sci. Res. 2018, 6, 123-130.

81. Goñi, P.; López, P.; Sánchez, C.; Gómez-Lus, R.; Becerril, R.; Nerín, C. Antimicrobial activity in the vapour phase of a combination of cinnamon and clove essential oils. Food Chem. 2009, 116, 982-989. [CrossRef]

82. Ojagh, S.M.; Rezaei, M.; Razavi, S.H.; Hosseini, S.M.H. Effect of chitosan coatings enriched with cinnamon oil on the quality of refrigerated rainbow trout. Food Chem. 2010, 120, 193-198. [CrossRef] 